\title{
العلاقات الخارجية للمملكة السبئية قبل الإسلام
}

الأستاذ: محمد كاكي، جامعة الجلفة، الجزائر

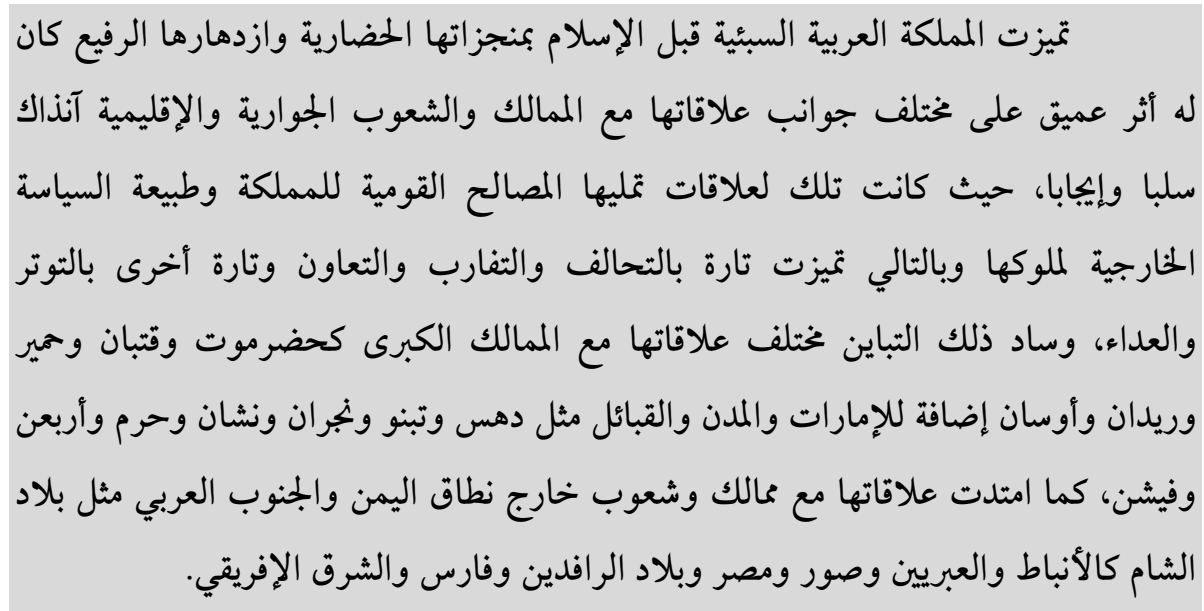

\section{Résumé:}

Nous avons souligné dans ce sujet les relations du royaume Arabe de Saba pré -islamique, car ce royaume ancien s'est caractérisé par plusieurs réalisations de la civilisation et la prospérité de haut niveau qui a eu un impact profond sur les différents aspects de ses relations avec les royaumes et les peuples voisins et régionales positivement et négativement, Le premier était à ses relations de voisinages avec les différents comme les royaumes et tribus et principautés arabes et des villes de l'Arabie du sud et du Yémen, en plus les royaumes et les peuples en dehors de la portée du Yémen et de l'Arabie du Sud. 
قامت المملكة العربية السبئية في الجنوب العربي من شبه الجزيرة العربية

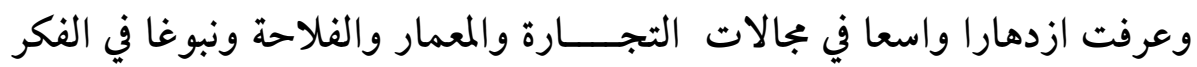
والمعتقد منذ ألفي سنة قبل الميلاد، وذلك ما جعل المعل الكثير من المؤرخين

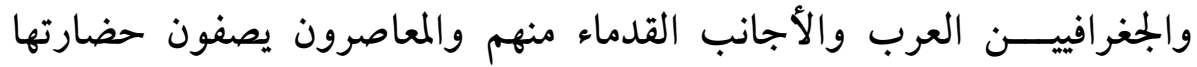

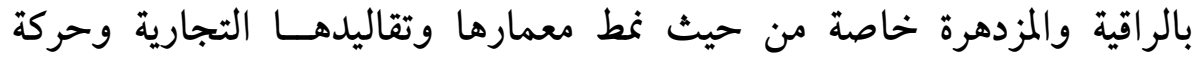

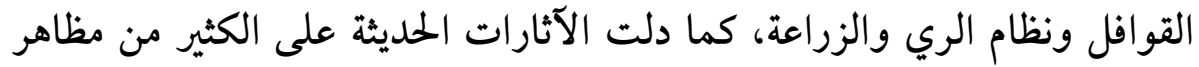

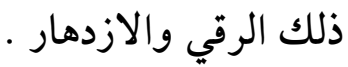

ولعل من أهم ما لفت انتباهنا كباحثين هو توسع علاقاتها الجوارية

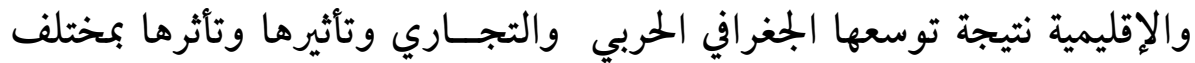
المظاهر الحضارية للممالك والشعوب الأخرى، تولية وكان لتلك العلاقات السبئية

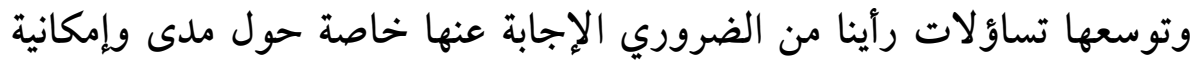

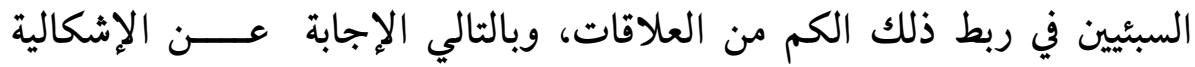
التي يطرحها يختلف الباحثين في مثل هذا الحـــال . وعليه سنحاول الإجابة بقدر الإمكان وباعتماد ما توفر من مصادر

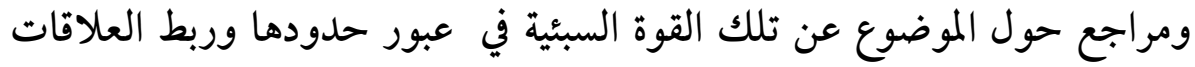

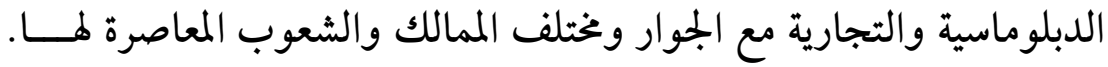
وسيكون تركيزنا في الإجابة عن تلك الإشكالية حول العلاقات الخارجية

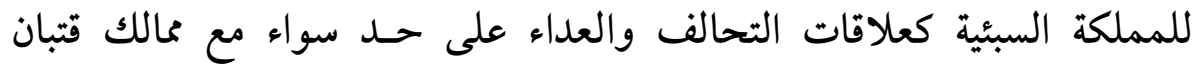

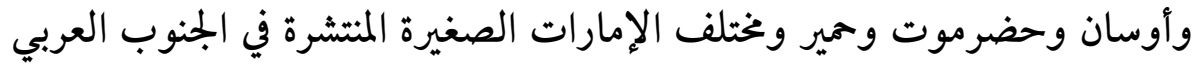




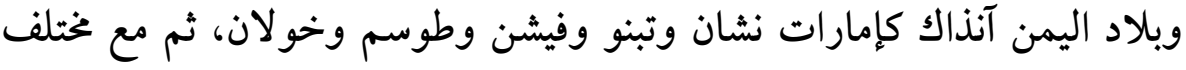

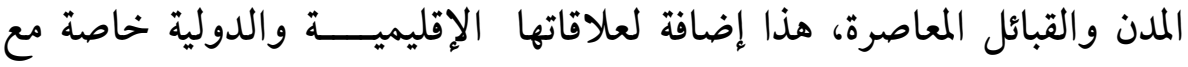

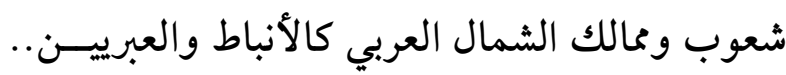

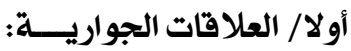

1 (العلاقات الجوارية

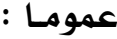

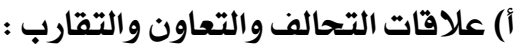

وطدت المملكة السبئية علاقاتها بالتحالف مع بعض الممالك الرئيسية

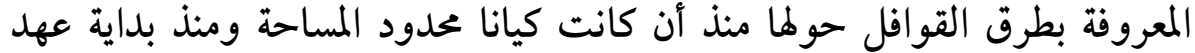

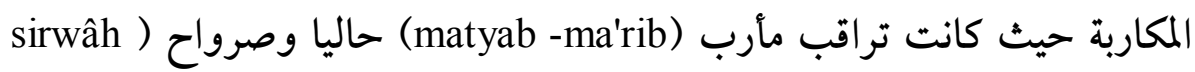
) والسفح الجنوبي للجوف وذلك لولوجها معربا معركة التنافس قصد بسط نفوذها

وسيطرتهـ (1) والمنت

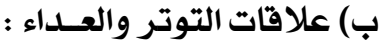

استمر السبئيون في محاولات للاستيلاء على جيرانهم من الممالك

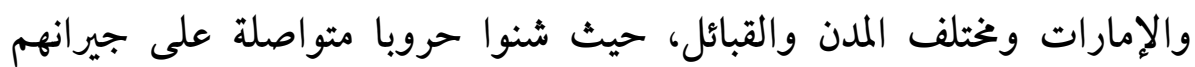

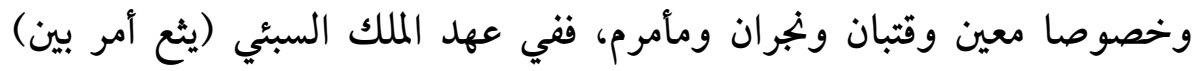

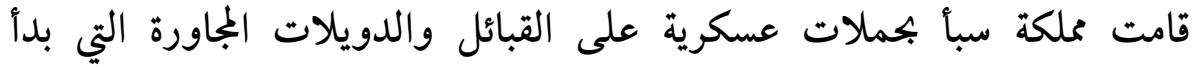

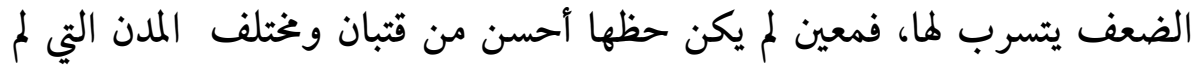

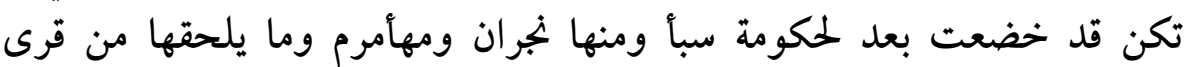

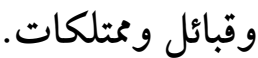




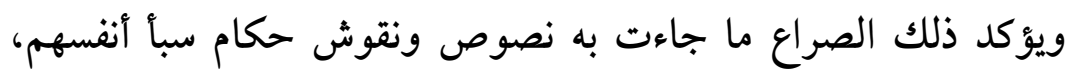

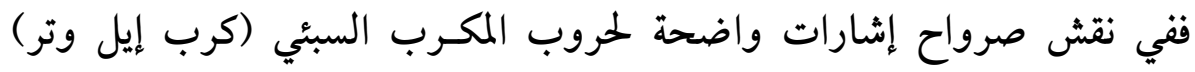

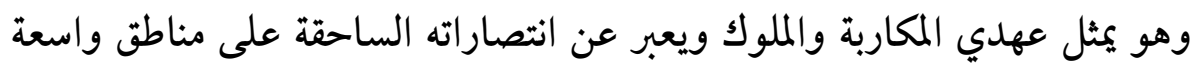

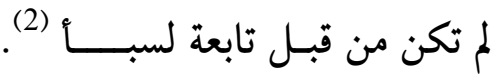

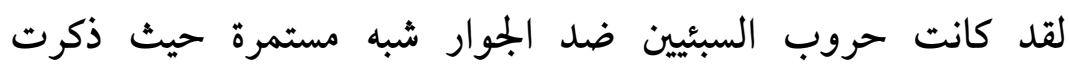

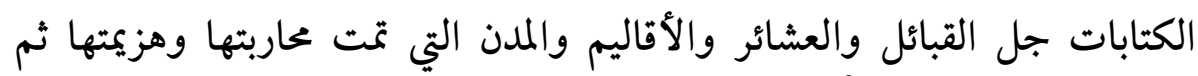

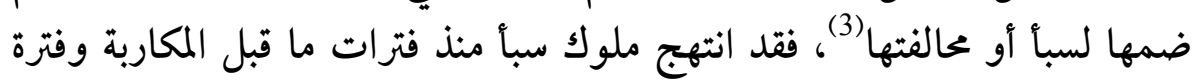

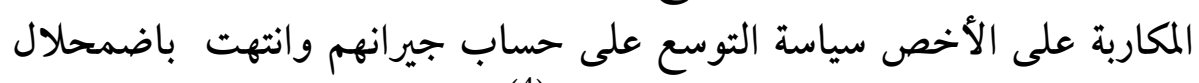
معظم تلك الكيانات في إطار الحكم السبئسي (4).

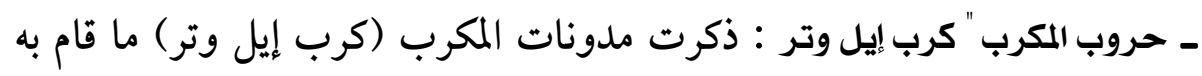

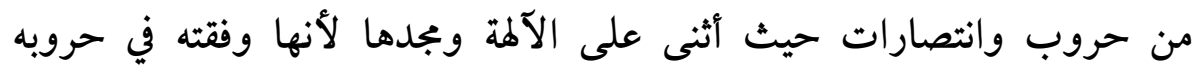

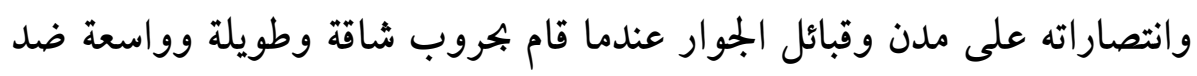

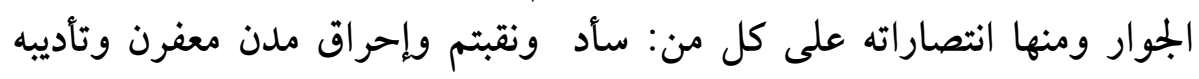

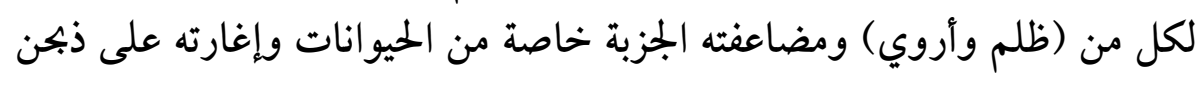

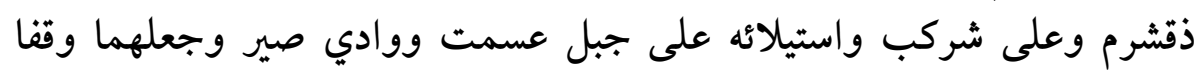

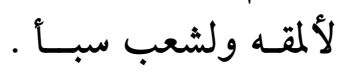

كما واجه كل من هرم وأوسان ونهب وسر وإلجاتم وإحراق مداق مدن أنفم

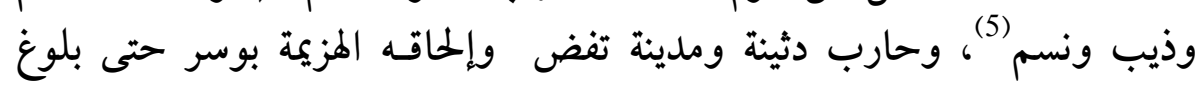
أرض أوسان وضمه سرم وتوابعها وحمدن ولوارئه دونها إلى حكومة سبأ، وسلم إدارة سرم الى السبئين أوسن وضمه

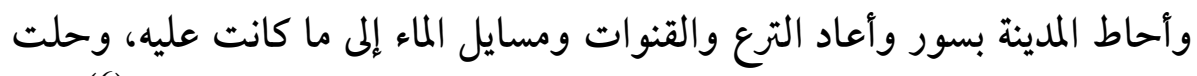

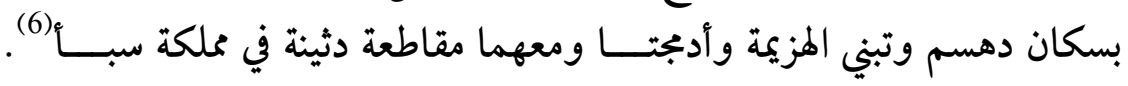

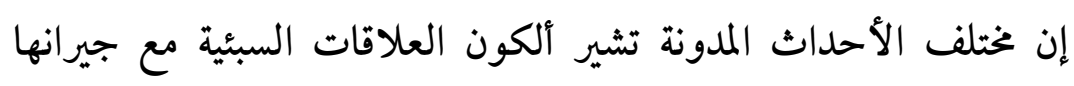

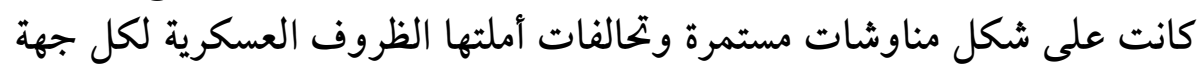


كما حدث في عهد المكرب المكرب (كرب إيل وتر) ضد أوسان مدافعة عن

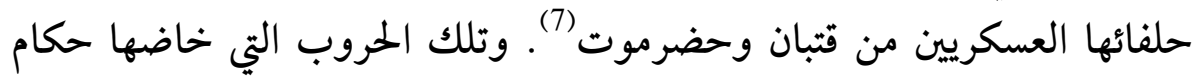

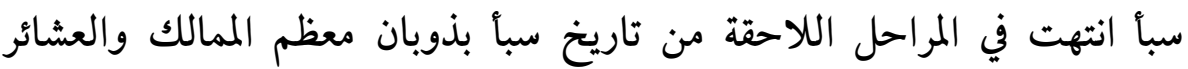
والمدن كمعين وقتبان وحضرموت سنة 450 ق.م أو القرن 2 ق. ق.م في المملكة المكان

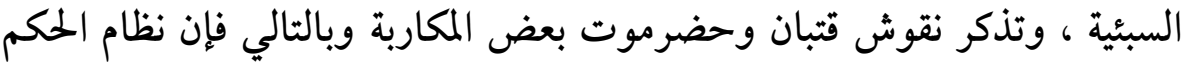

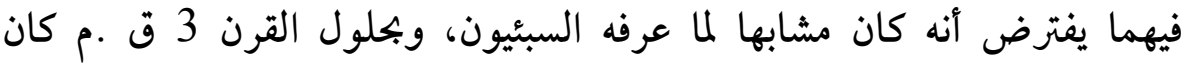

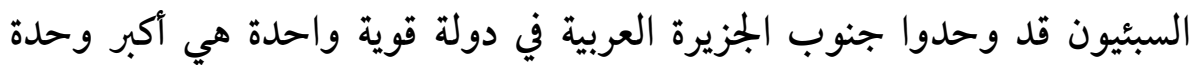

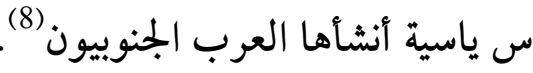

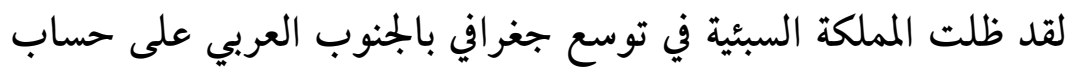

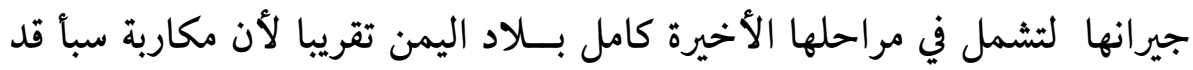

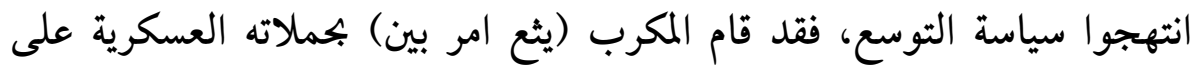

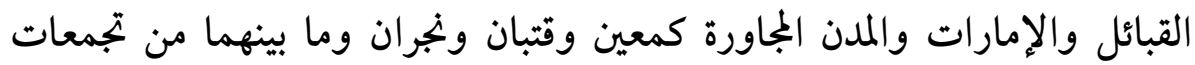

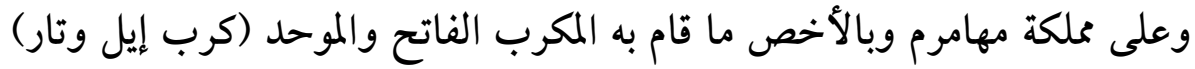

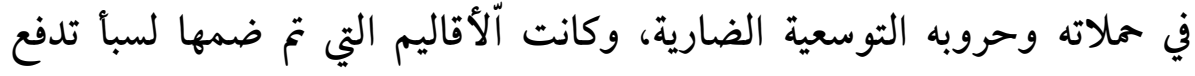

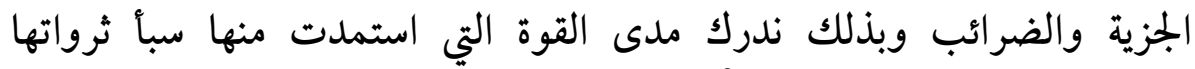

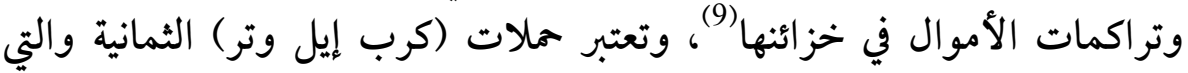

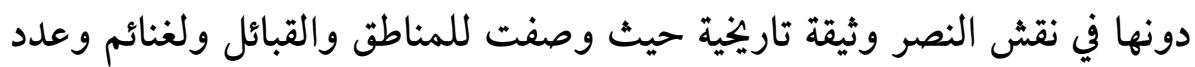

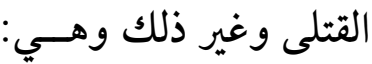
ـ الحملة الأولى: وجهت نحو الجنوب الغربي أو الجنوب الشرقي ضد معافران . DHubhan وذبهان Mafran ـ الحملات: الثانية والثالثة والرابعة: وجهت ضد أوسان بوادي مرخا Wâdî markha ـ الحملات:الخامسة والسادسة: وكانت ضد مدينة نشان Nashshân حاليا بالسويداء ميدان الخرائب إلى الشمال من مأرب في الدلتا الكبيرة الجافة لوادي

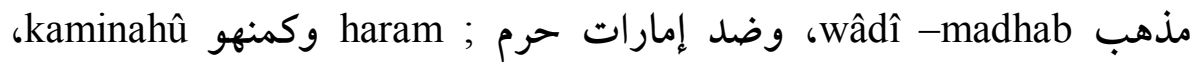


والتي انتشرت على طول الوادي خلال القرن السابع ق.م ، وبدأت تهلدد مصالح

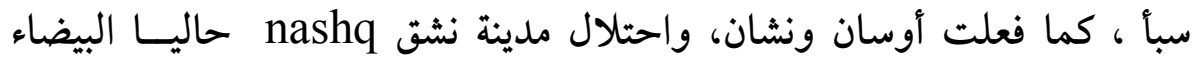
التوأم لمدينة نشان بعد 3 سنوات من الحصــار .

ـ الحملة السابعة: فتشير لبعض المدن التي لم تتحد بعد، والتي تقع احتمالا في

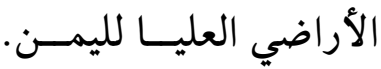

ـ الحملة الثامنة: وهي الأخيرة ووجهت لمحاربة وضم مجموعة قرى يحتمل أن أن تكون

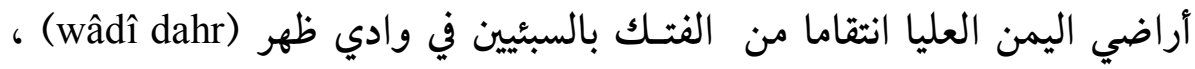

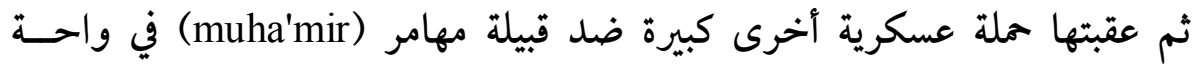

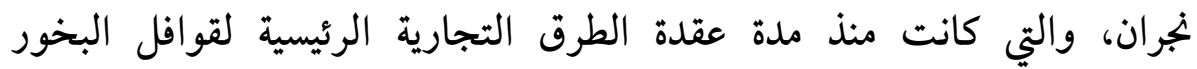

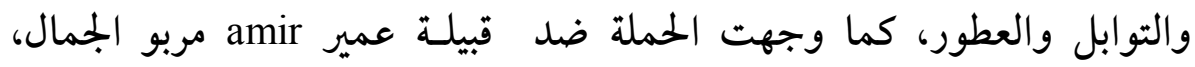

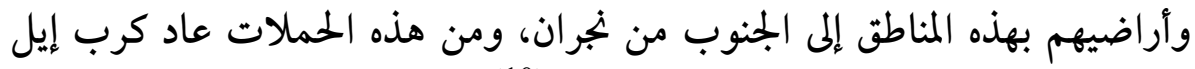

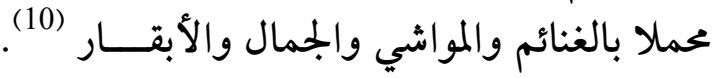

ـ حروب الملك يثع أمر بين ضد الجوا ر: قامت سبأ بحروب نوسعية جوارية في عهد

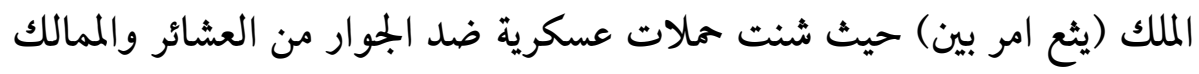

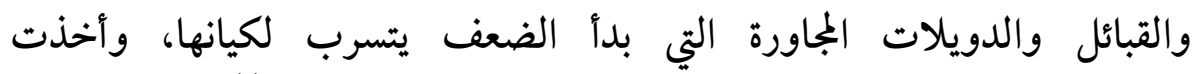
حكوماتهـا تسير نحو الزوال كقتبان ومعين حتى نجران ومهأمـرم (11).

وقد بدأ هذا الملك بحملاته المثواصلة ضد جيرانه من قبائل ودويلات

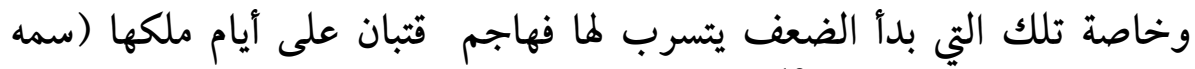

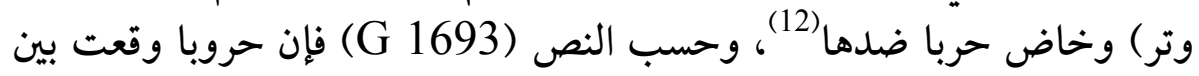

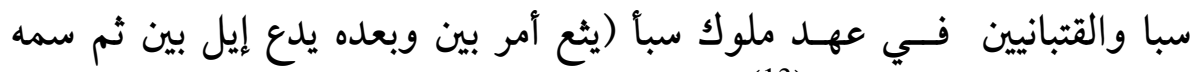
علي ينف ويثع أمر وتـــر) (13). حروب وهب إيل يحز: وفي النص الموسوم بالرمز (G 1128) أن الملك السبئي وهب

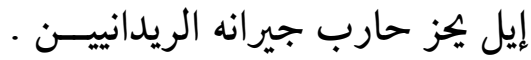


ويرى المؤرخون أن هذا الصراع السبئي الجواري بقدر ما أدى للتوسع الأحس

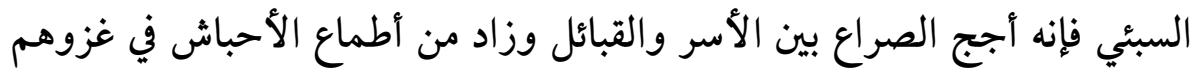

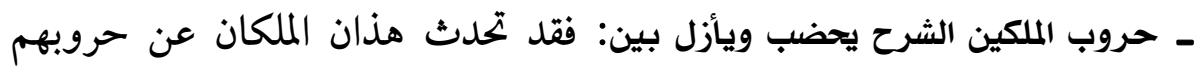

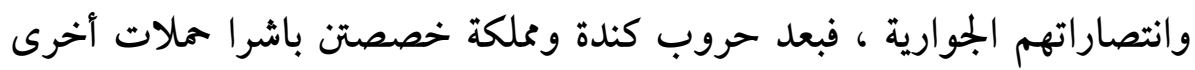

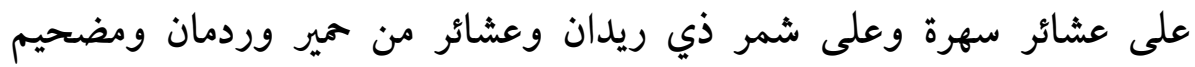

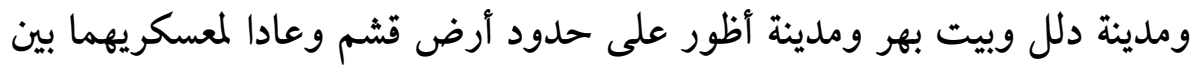

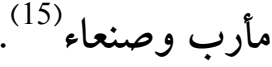

ـ حروب الملك يثع أمر بين: لقد ساد التوتر مع كثير من المناطق الجوارية كقتبان

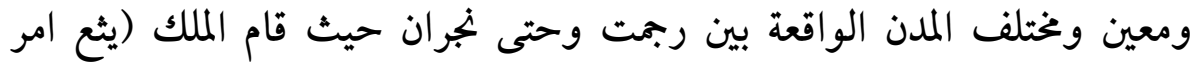

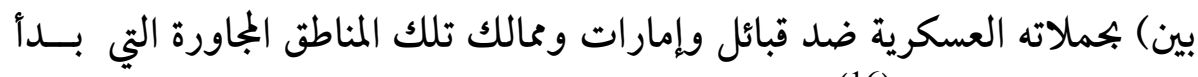

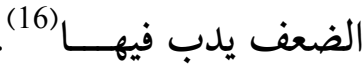

- في عهد ملوك سبأ: تطور الصراع بين السبئين والقبائل والإمارات المجاورة ، ومنها

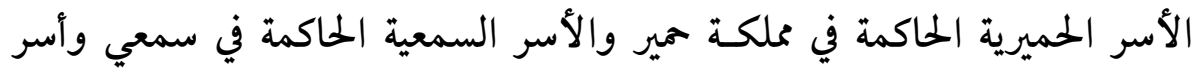

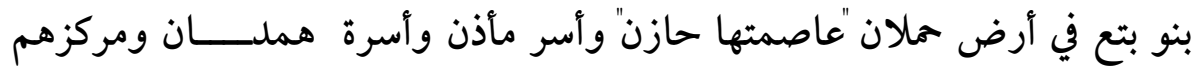

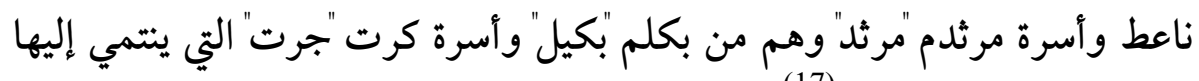

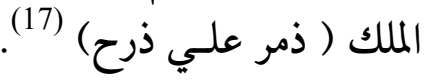

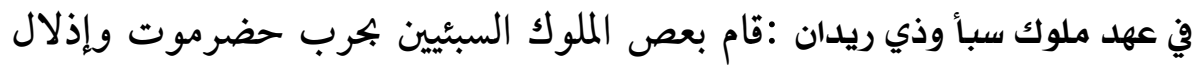

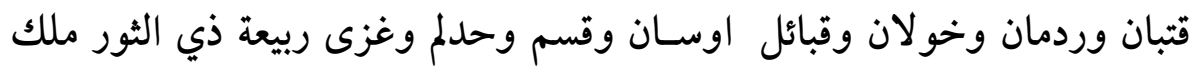

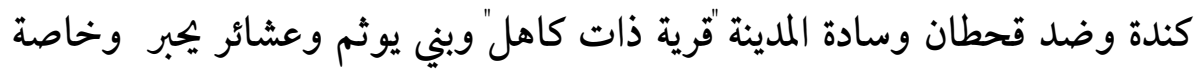

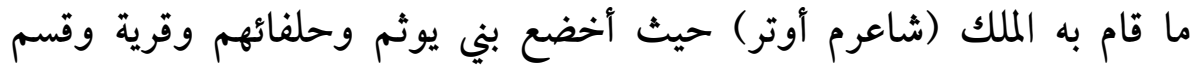

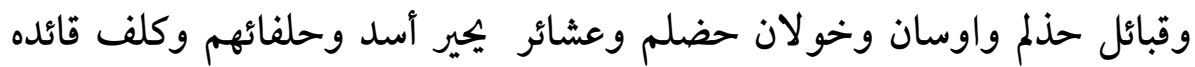

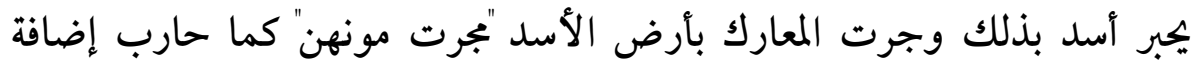

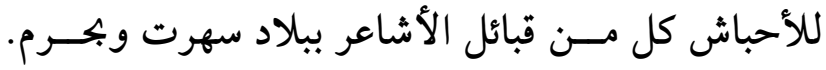


ويشير لتلك الحروب والمعارك بين شاعرم أوتر والجوار من مجموع القبائل

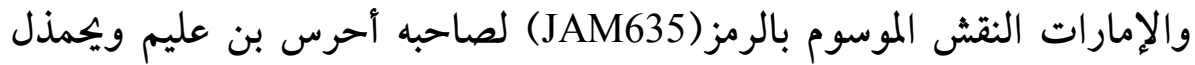

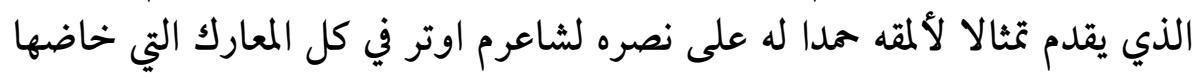

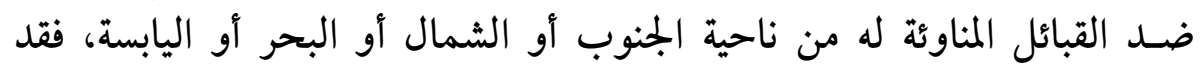

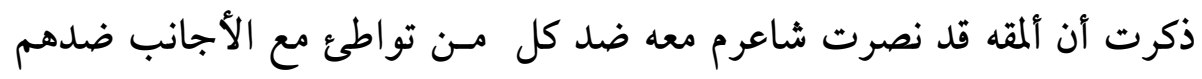

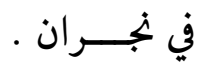
ـ حروب الملك شاعرم أوتر: لقد واصلت سبأ في عهد ملوك سباً وذي ريدان سياسة

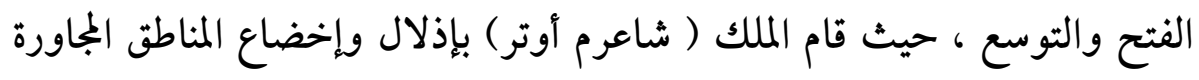

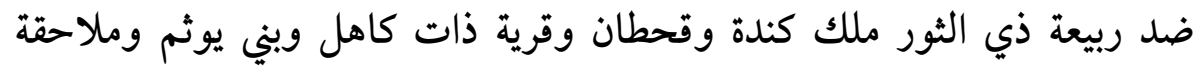

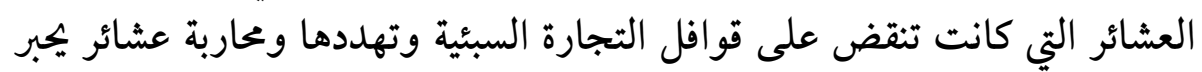
أسد التي تعاونت مع بني يوثم (18).

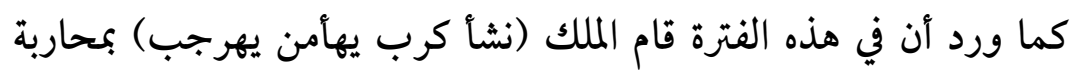

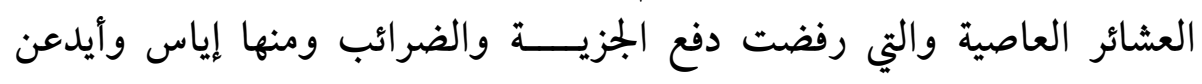

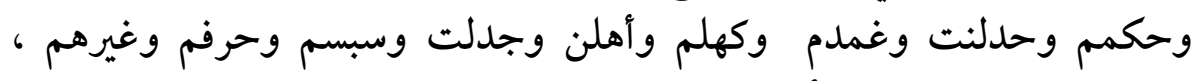

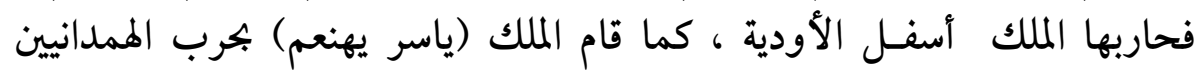

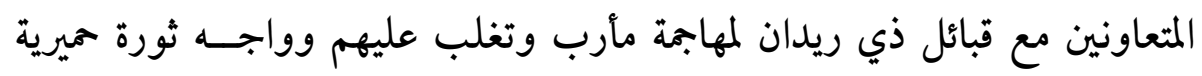

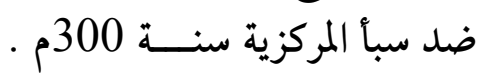

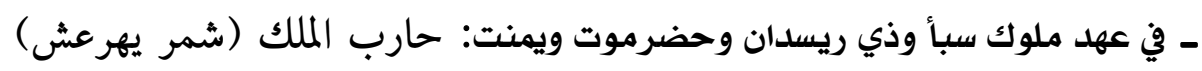

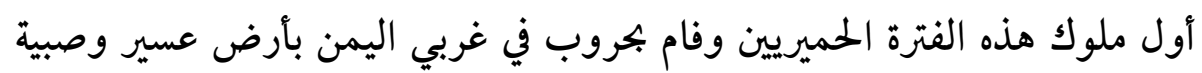

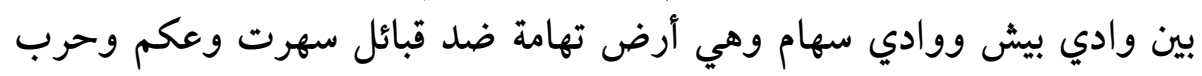

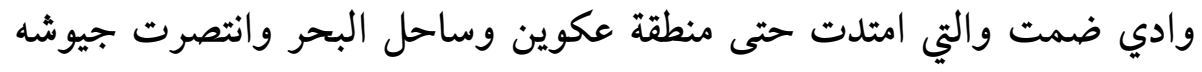

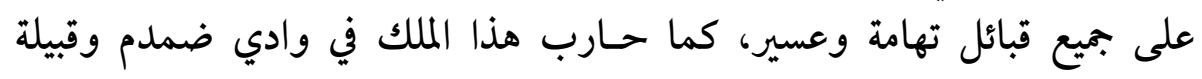

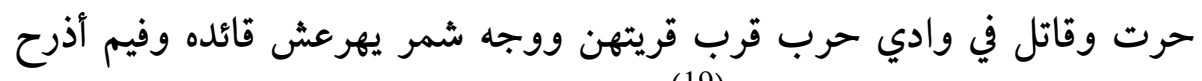

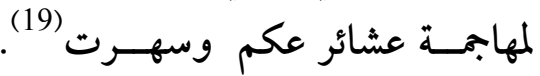


*) وجود الممالك والإمارات: ظهرت بالجزيرة العربية عموما أنواع من نظام الممالك

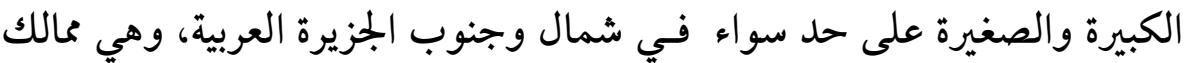

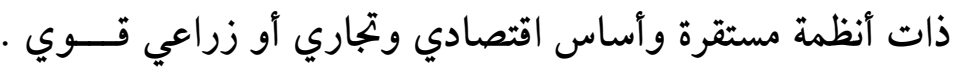
ـ نظام الممالك الكبيـرة : ومنها ممالك حمير وقتبان وحضرموت وسبأ ومعين ... ـ نظام الممالك والإمارات الصغيرة: ومن هذه الممالك ما انتشر بالشمال ومنها ما هـ انتشر بالجنوب العربي، فهذا النوع مــن النظم أملته الظروف الاجتماعية والاقتصاديــة . باتجوت. * ) واقع العلاقات وتطوراتها: عرفت العلاقة بين سبأ وجيرانها فترات تعاون

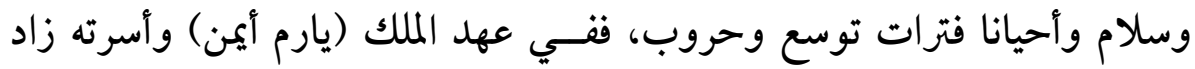

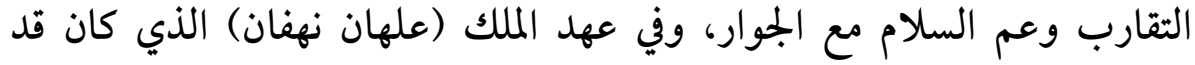

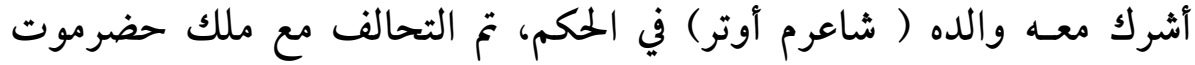

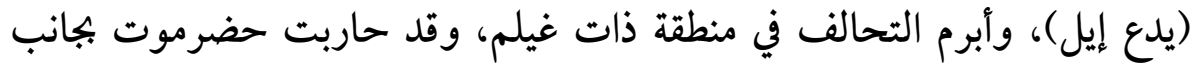

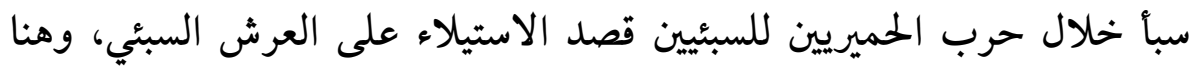
حالف ملك سبأ (المرحلة "1 من العصر 3") علهان نهفان حضرموت لأنه كان في الأني صراع الأسرة الحميرية، وهذا التحالف اقتضته المصلحة العسكرية بين القبائل،

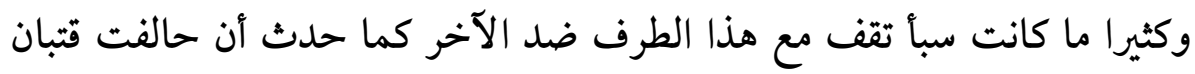

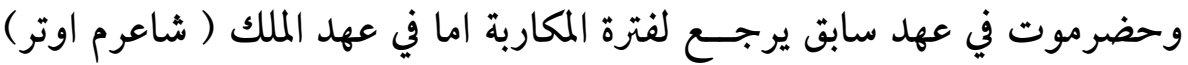

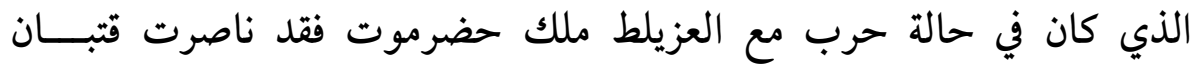
حضرمــــوت.

ب) العلاقة مع الحضارمة: تعتبر حضرموت من ممالك الجنوب الكبرى عاصمتها

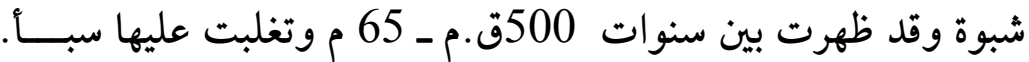




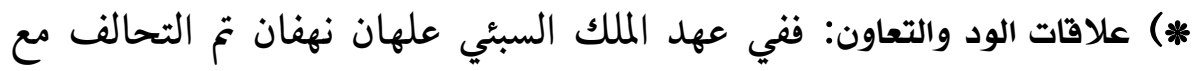

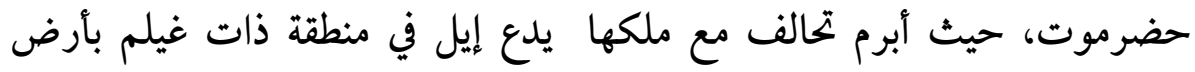

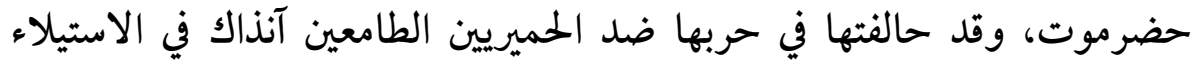

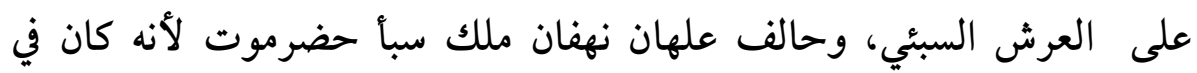

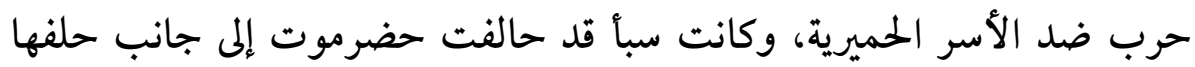
مع قتبان في وقت سابق يعود لفترة المكاربـــة.

ـ وفي عهد المكرب كرب إيل وتر: حالفت حضرموت سبأ في حربها ضد أوسان،

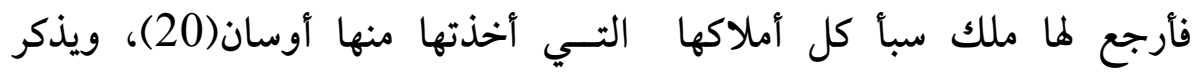

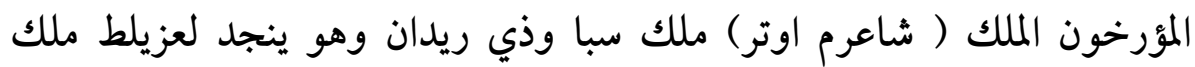

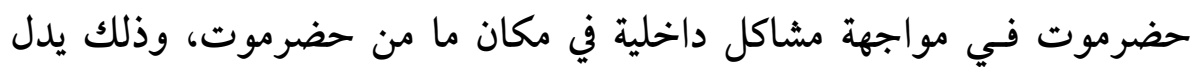

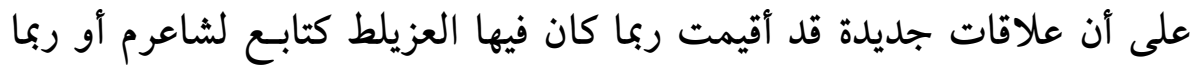

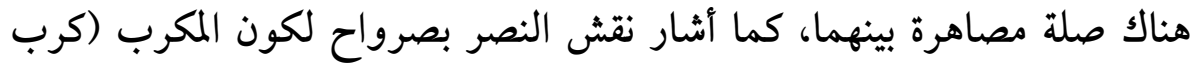

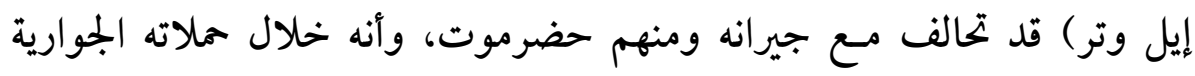

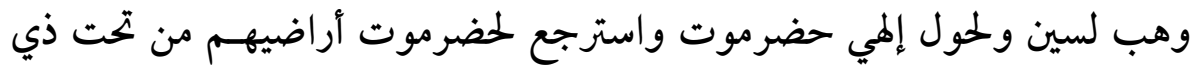

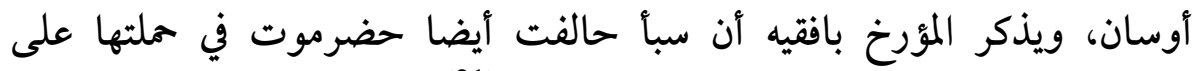

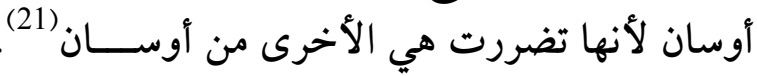

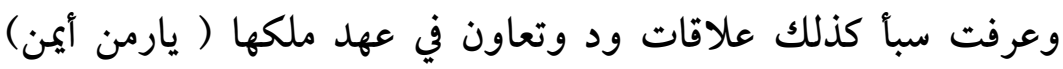

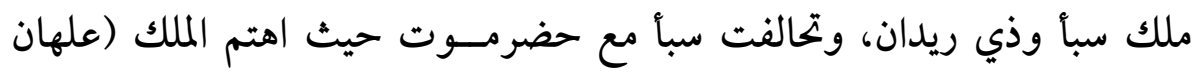

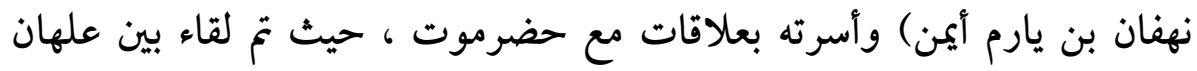

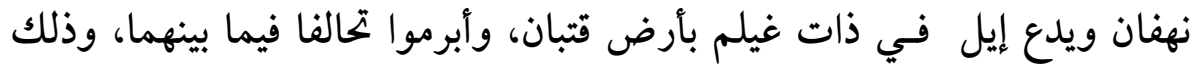

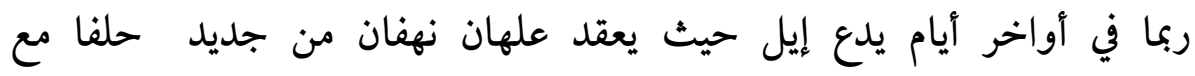

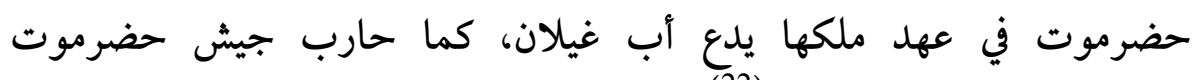

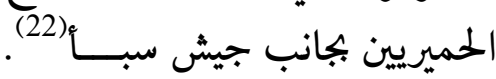


(*) علاقات التوتر والحروب : (*)

وفي فترة من فترات الحرب بين سبأ وحضرموت ناصرت قتبان

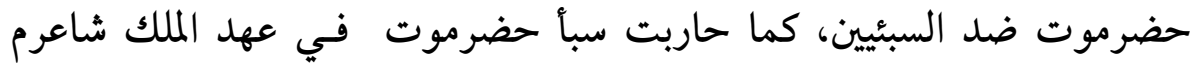

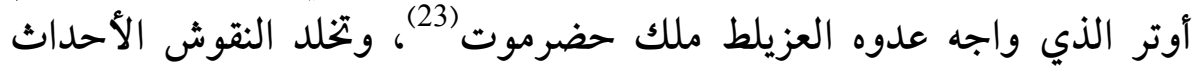

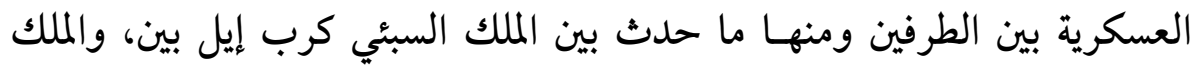

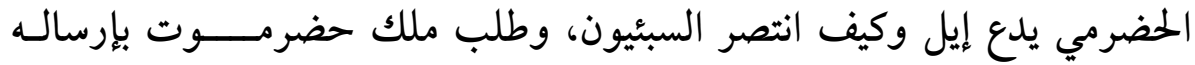

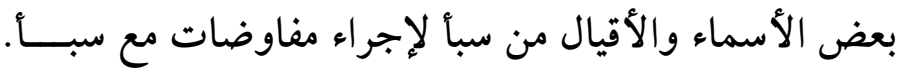
وفي عهد الملك السبئي شاعرم أوتر ملك سبأ وذي ريدان جرت الحرب الحب

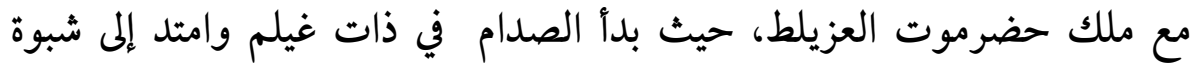

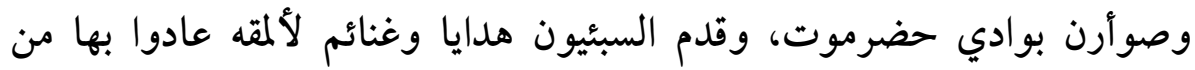

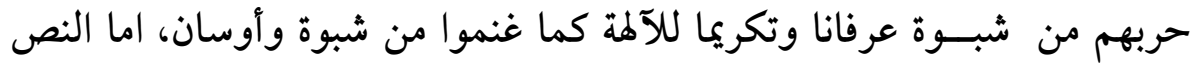

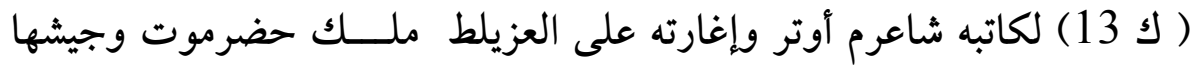

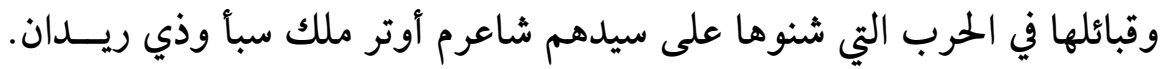
وفي عهد الملك السبئي شمر يهرعش ملك سبأ وذي ريدان وحضرموت ويمنت يذكر أن حضرموت كانت يومها تحت حكم ملكين هما: شرح آل آل

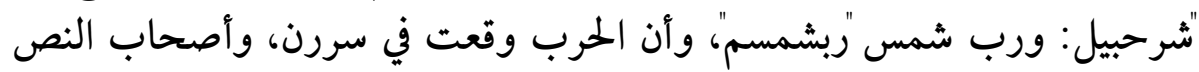
كانوا من أهل سبأ كهلان ، ولسيطرة سبأ على حضرموت يشير النص (Ja662)

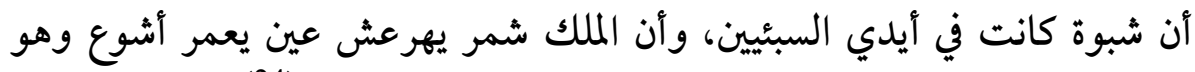

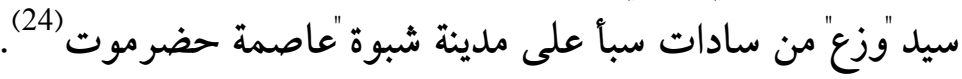
لقد خاضت سبأ في تلك الفترة حربا ضارية مع حضرموت وجوارها وكلف الملك السبئي ياسر يهنعم وشريكه في الحكم إبنه (ذرأ أمر أيمن) قائده كبير

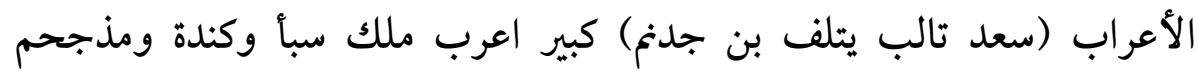


وحرمم وبهلم وزيــدال وعلى كل أعراب سبأ وممير وحضرموت ويمنت، وقد

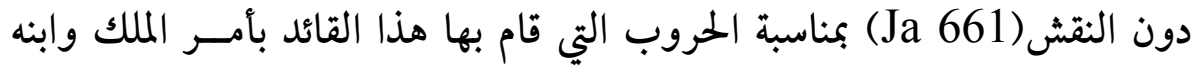

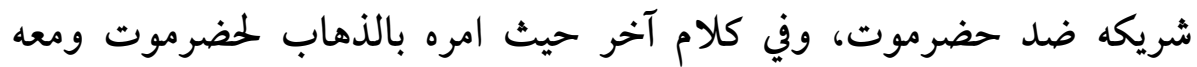

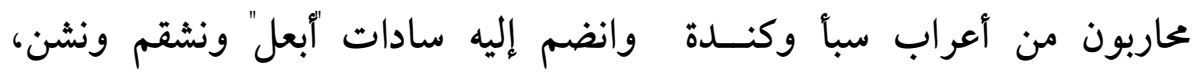

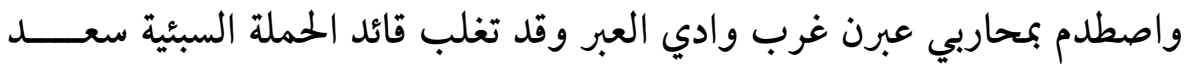

تالب يتلف على الحضارمة، ثم سار بجيشه لدهر ورخيت والأراضي المنخفضة

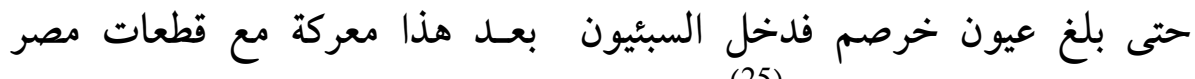

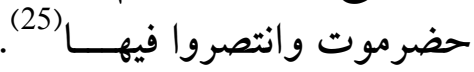

وحاربت مملكة سبا في عهد الملك (كرب إيل بين بن ذمر علي ذرح)

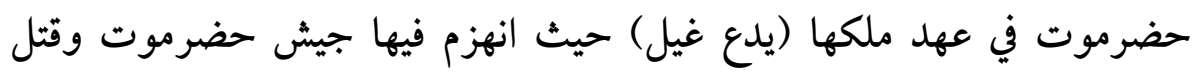

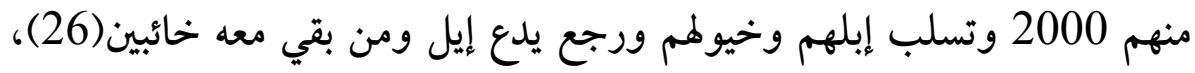

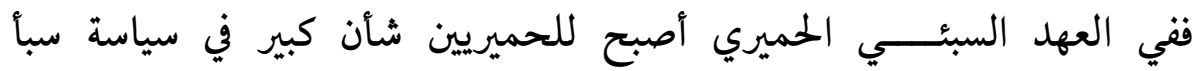

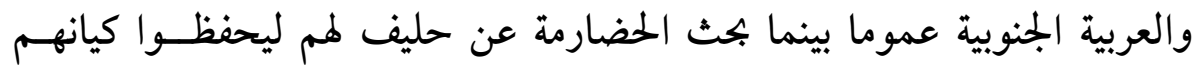

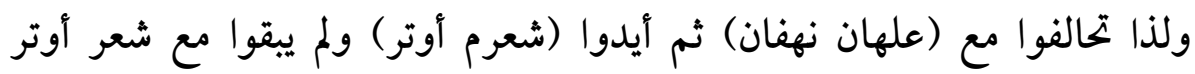
طويلا، وأرادت حضرموت ضم أرض ردما ردمان لها وهي أرض تابعة لمملكة قتبان

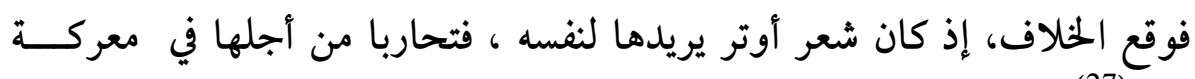

ويشير النص أن الردمانيين إنتهزوا فرصة حرب شعر أوتر ملك سبأ وذي

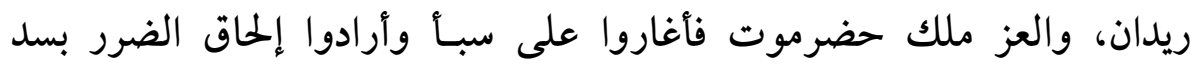

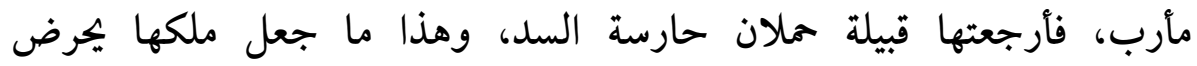

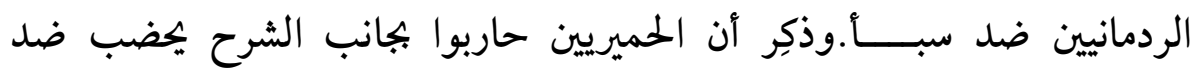

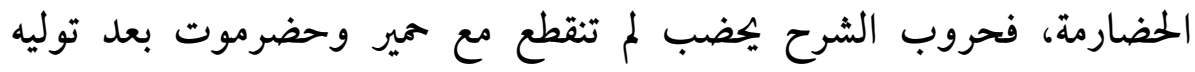

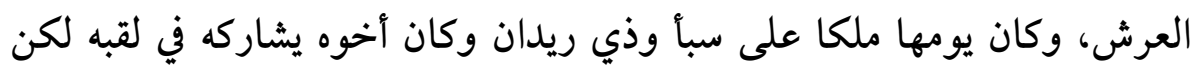

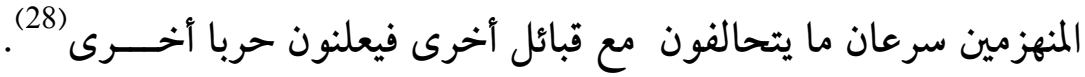




\section{ج) العلاقات مع القتبانييـن:}

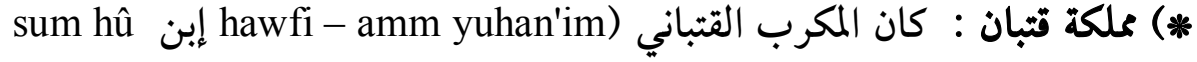
(watar

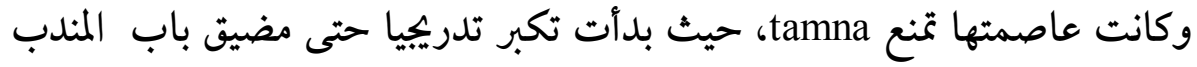

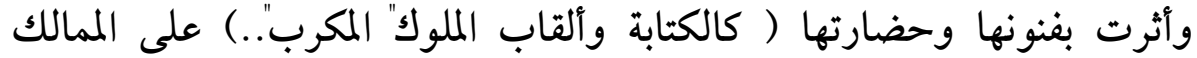

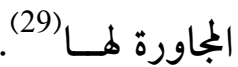

* (*) علاقات الود والتعاون: (*)

كانت قتبان قد آزرت سبأ أثناء حربها مع أوسان في عهد الملك السبئي كرب إيل وتر وقد كافئها بأن أعاد لها كل أملاكها التي أخذتها منها أوسان أوسان

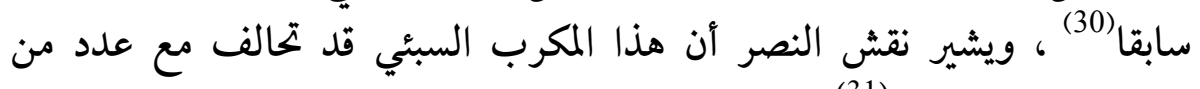
جيرانه ومنهم قتبـان (31). وأنه بذلك عرف تقاربا مع ملك قتبان، كما ساعد ملك قتبان السبئين في

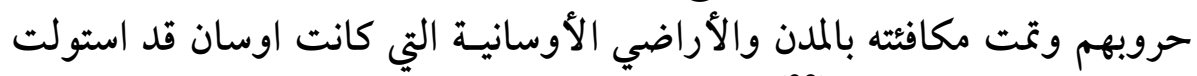
عليها في ظروف سابقــــة (32). *) علاقات التوتر والحروب: (*)

قامت سبأ بمهاجمة القتبانيين في عهد المكرب (يثع أمر بين) وكان ملكهم

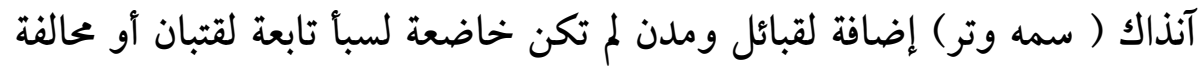

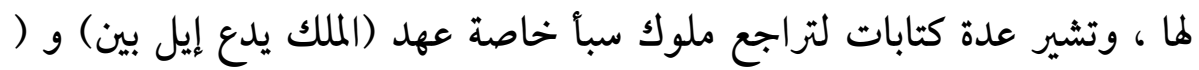

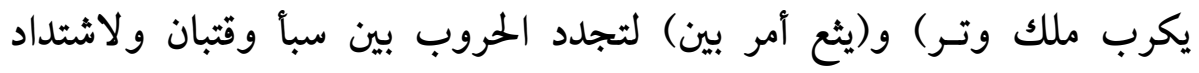

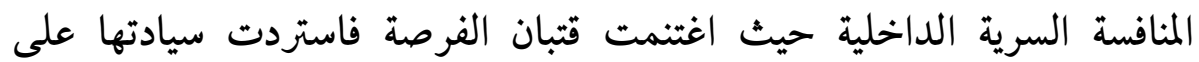

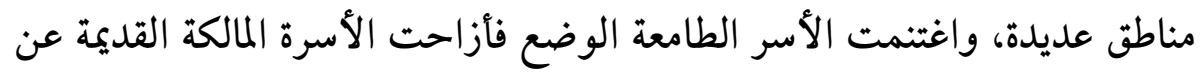

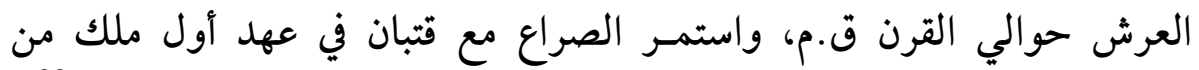
الأسرة الجديدة ( سمه علي ينف) ، ومنذ القرن 1 ق. قم احتوت سبأ كل قتبان (33). 
ففي عهد الملك (يثع أمر بين) قامت سبأ بحملات متواصلة على جيرانها

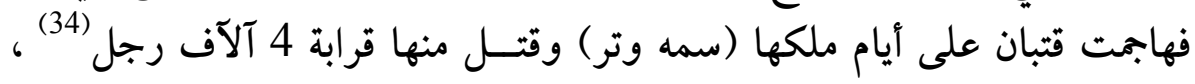

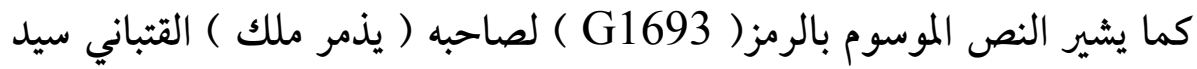

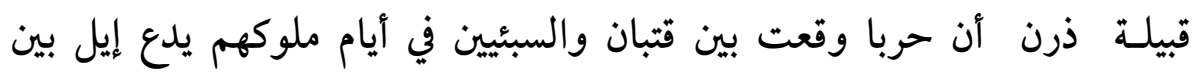

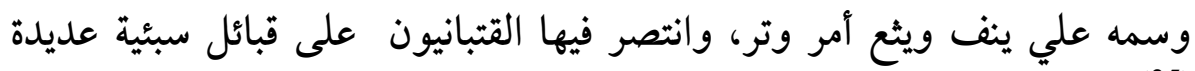

كما تذكر الروايات أن المكرب السبئي كرب إيل وتر حارب القتبانيين في

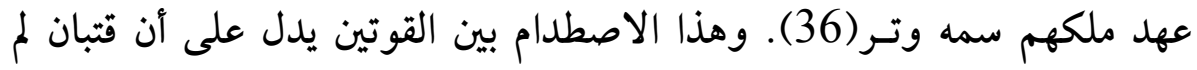

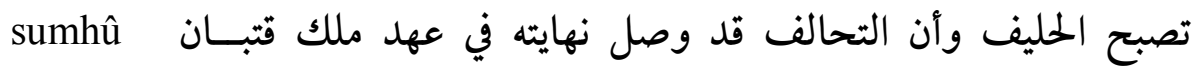
watar

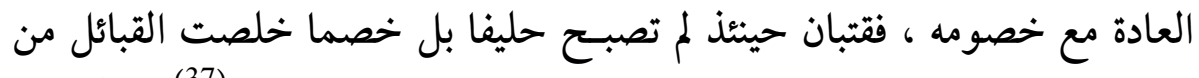

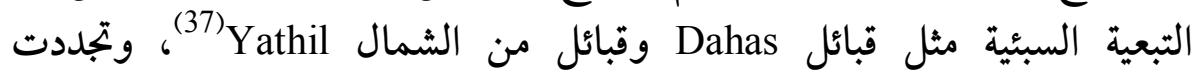

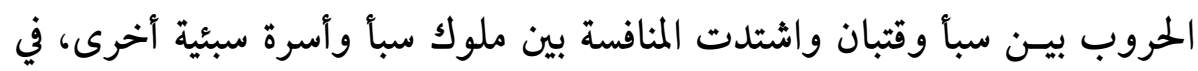

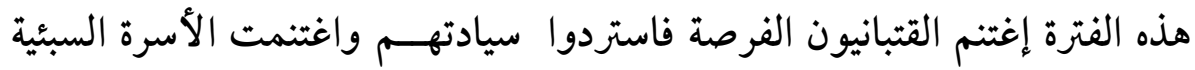

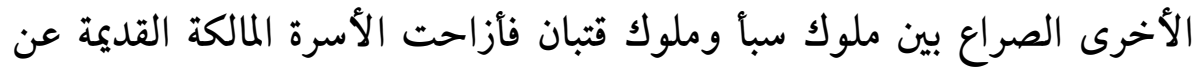

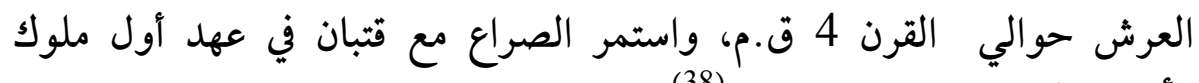

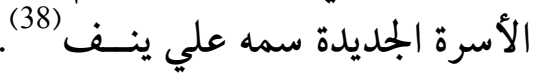

وفي عهد ملوك سباً (المرحلة 2 من العصر2) وردت نصوصا ونقوشا

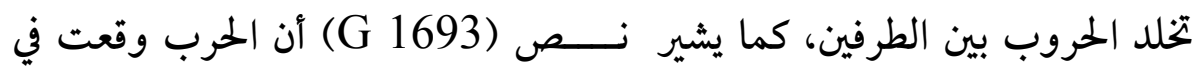

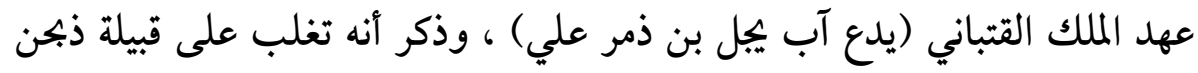

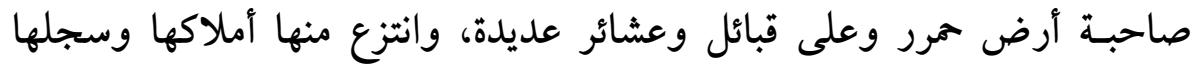

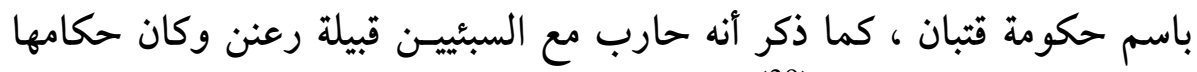

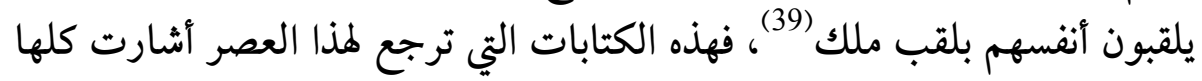

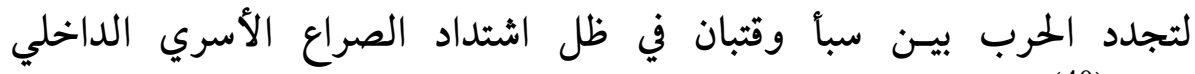


د) العلاقات مع الحميريين والريدانيين: * العلاقات مع الحميرييـن:

في أثناء الحرب الحميرية السبئية قصد الاستيلاء على العرش السبئي حالفت حضرموت سبأ، أما حربها مع الريدانيين فيظهر من خلال حرب المبيديه الملك السبئي (وهب إيل يحز) للريدانيين في عهد رئيسهم (ذمر علي) وذلك في حدود سنة 180

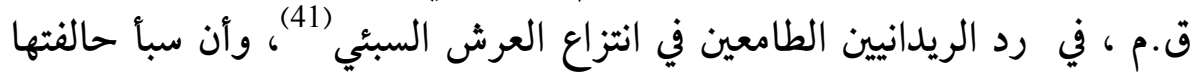

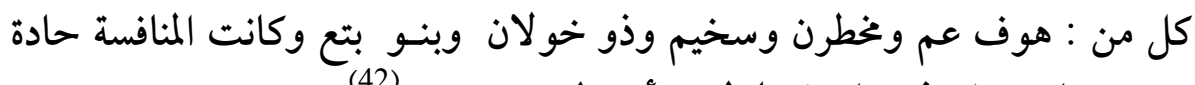

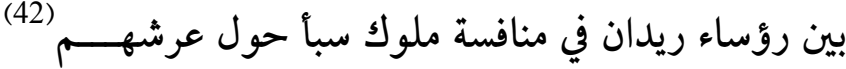

لقد حارب ملكي سبا وذي ريدان الشرح يخضب ويأزل بين شمر ذي

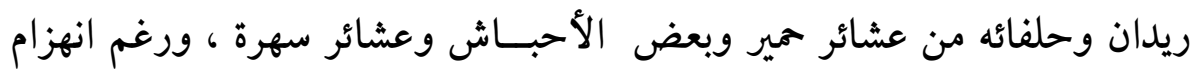

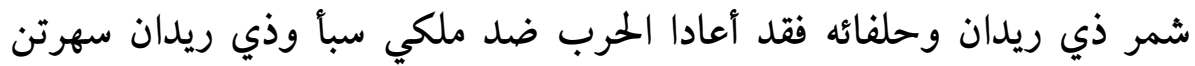

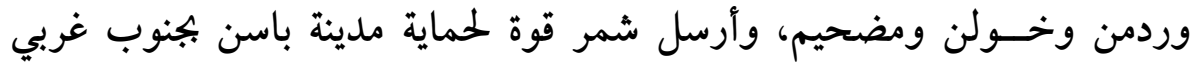

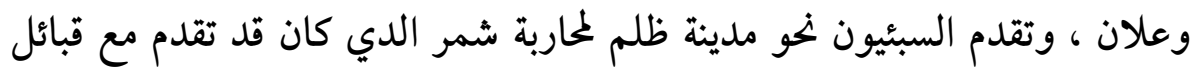

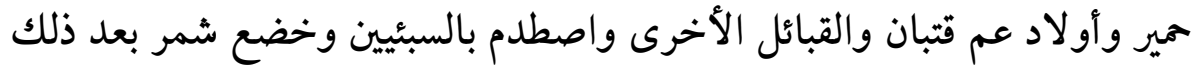

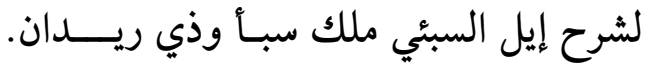

لقد بدأ التوتر وبدايات الصراع بين السبئين والحميريين منذ عهود مبكرة، ففي مرحلة ملوك سباً اشتد التنافس بين السبئيين ومختلف القبائل المناوئة

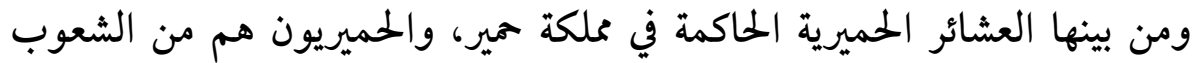

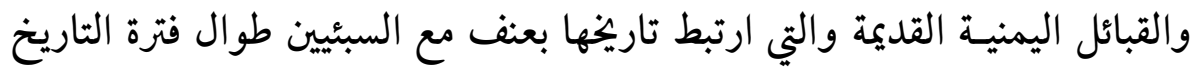

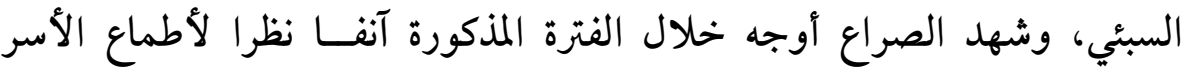

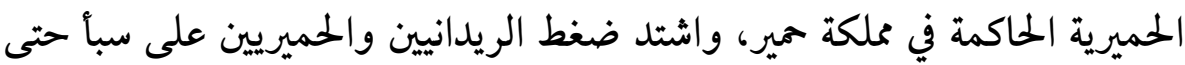

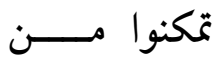

الانقضاض على عرش المملكة السبئية وهو ما تم لفم خلال سنة 115 ق.م نتيجة

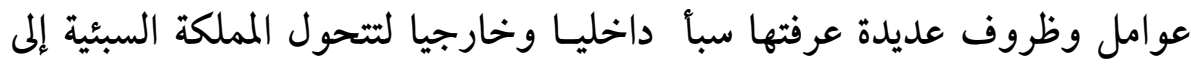


مرحلة جديدة من تاريخها وهي مرحلة ملوك سبأ وذي ريدان أي فترة المملكة

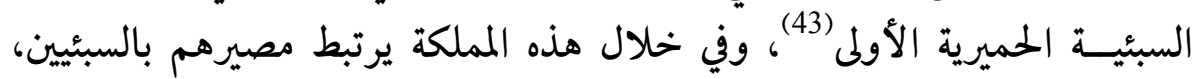

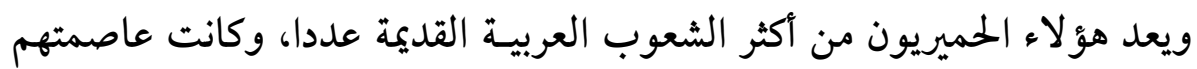

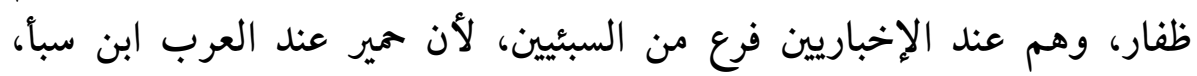

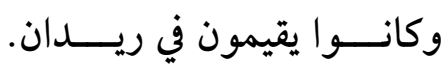

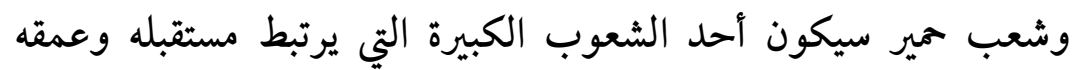

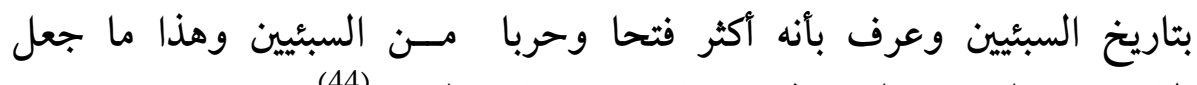

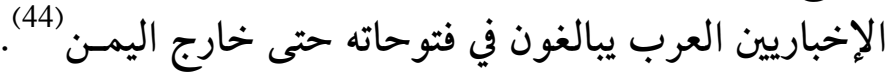

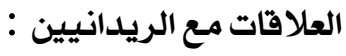

لقد حاربت سبأ الريدانيين ففي عهد ملكها (وهب إيل يمز) في حدود

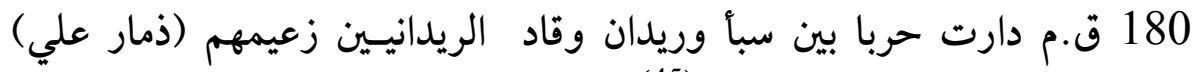

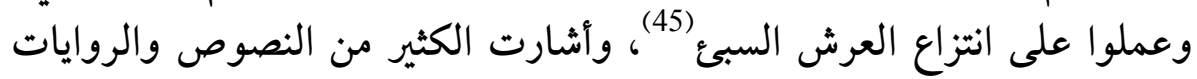

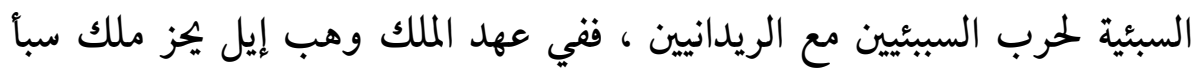

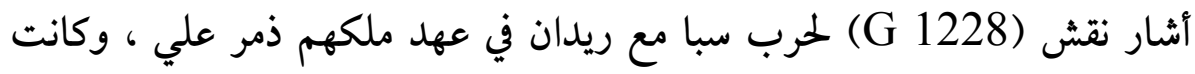

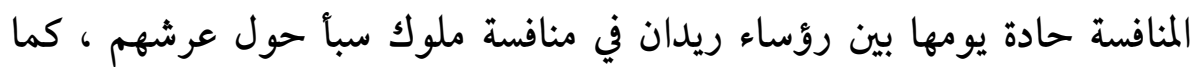

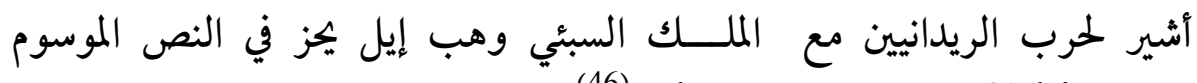
بالرمز (Ja 561.bis) لصاحبه يرم أيمن (46).

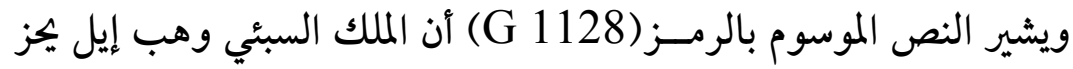

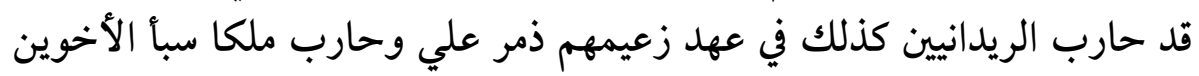

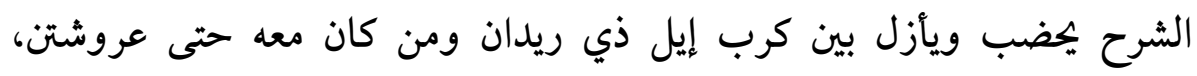

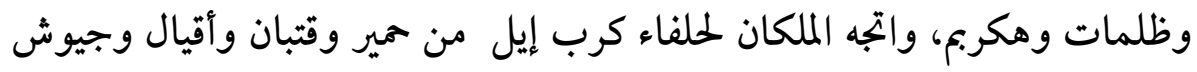

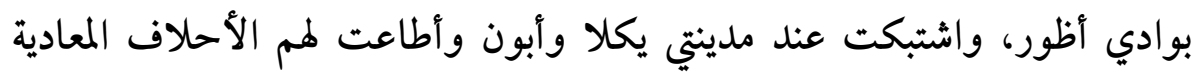

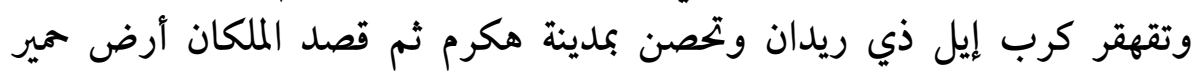

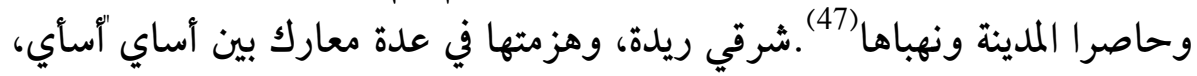




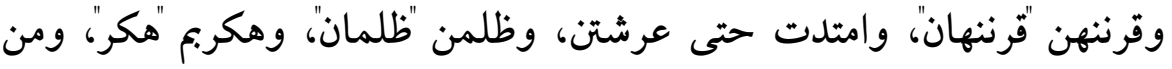

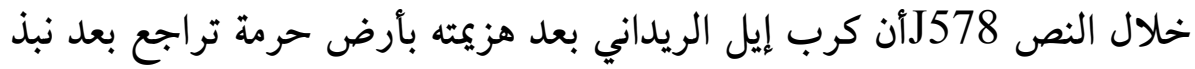

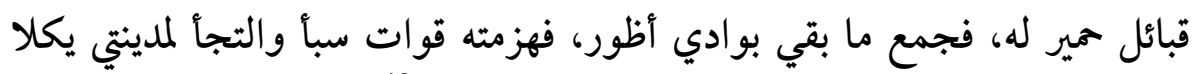

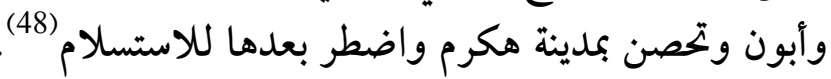

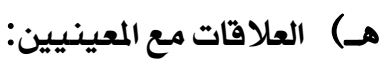

لقد استغل السبئيون منذ البداية ومنذ المراحل الأولى ضعف المعينيين

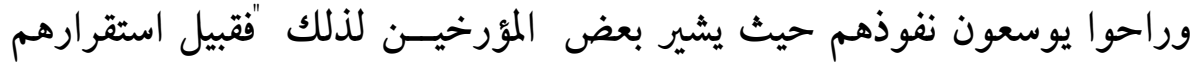

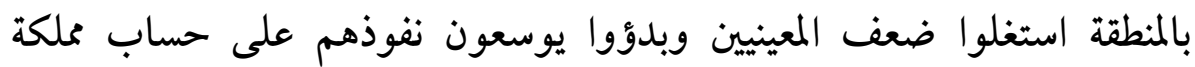

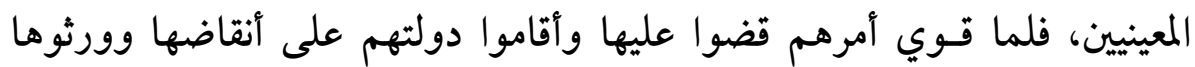

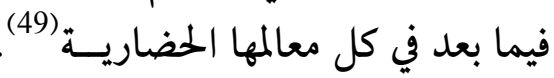

ونلاحظ ذلك التوتر في سياسة وأطماع السبئين من خلال سياسة الحاكم

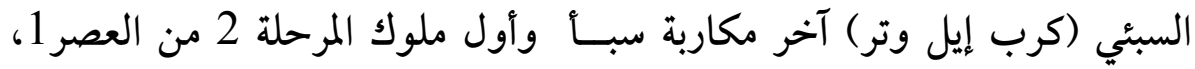

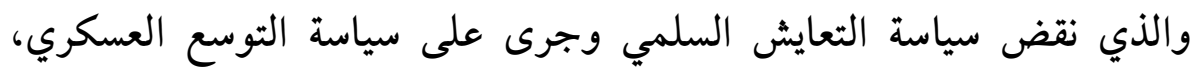

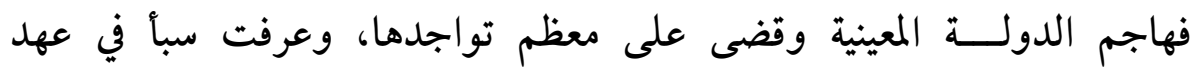

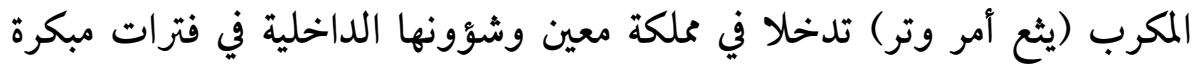

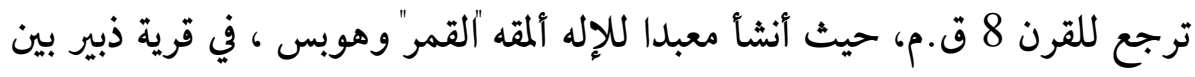

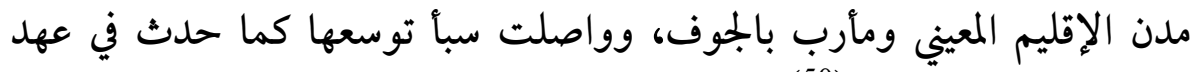

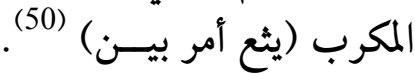

لقد شرع السبئيون في التوسع على حساب جيرانهم وخاصة المعينيين،

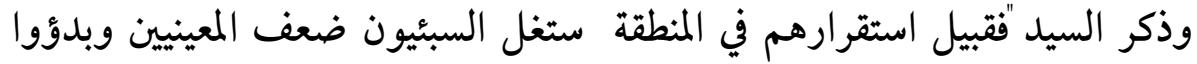

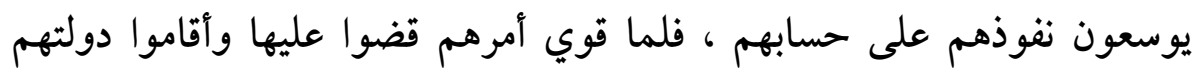

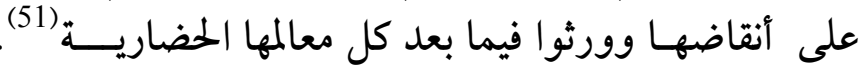

بدأت محاولات السبئين المستمرة لضم معين والاستيلاء عليها منذ تحصينهم لمدينة نشق المعينية بالجوف في عهد المكرب يدع إيل بين، وخليفته لمعن يثع أمر 
وتر لأن السبيين قد أعلنوا الحرب ضد خصومهم في معين وقتبان ونجران

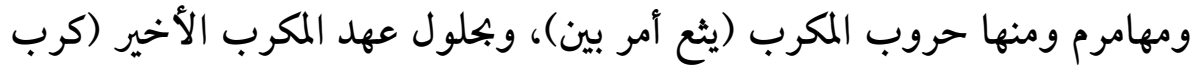

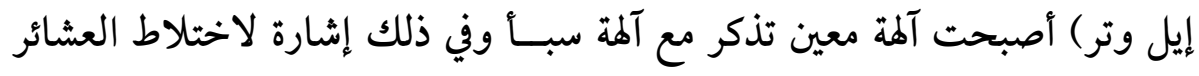

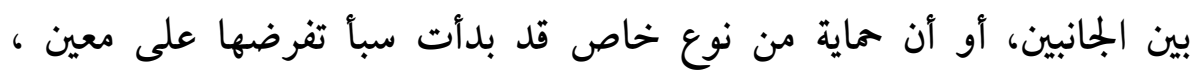

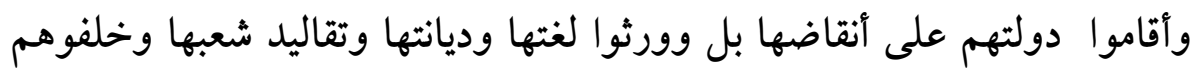

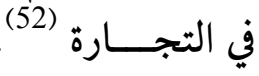

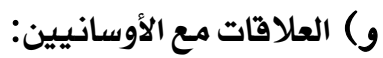

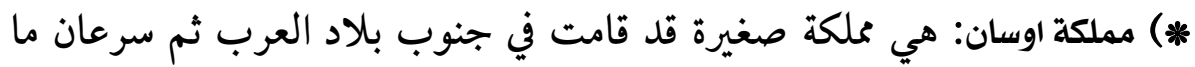

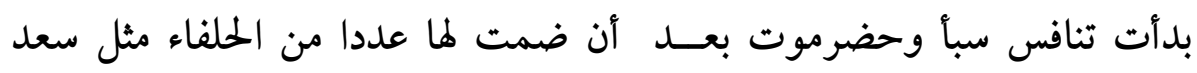

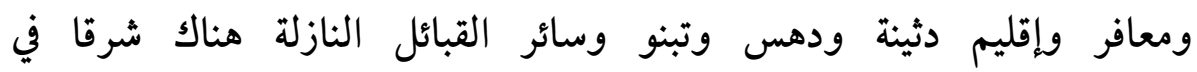
حضرمســـوت ومافيم

*) العلاقات مع الأوسانيين: تميزت العلاقات السبئية الأوسانية مثل غيرها بالعداء

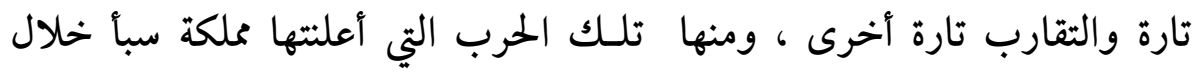

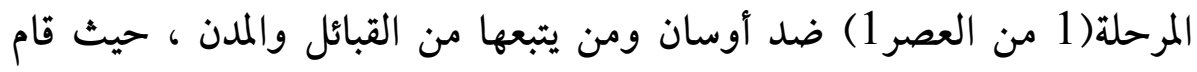

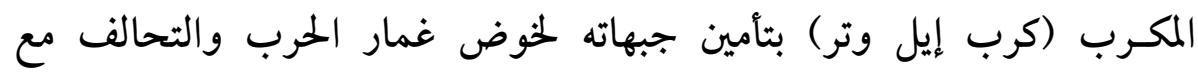

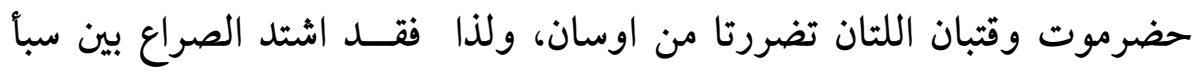

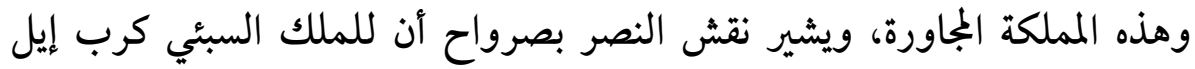

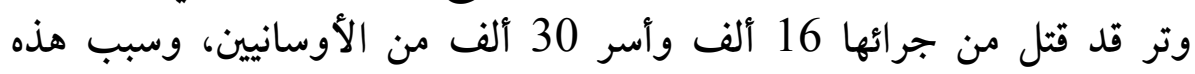

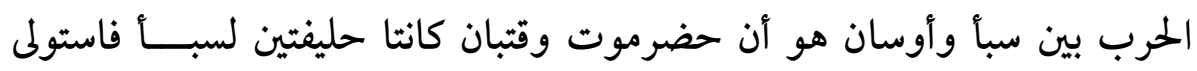

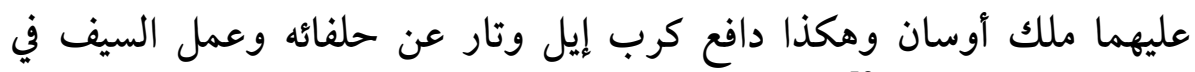
أوسان حتى أخضعها ملو أوسان (53).

لقد حارب المكرب كرب إيل أوسان في عهد ملكها مرتوم وحطم القصر الملكي "مسور (54). 
وقد أصبحت أوسان خصمـا عنيدا لسبأ تراقب إقليما واسعا من اليمن

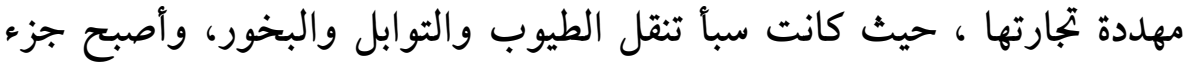

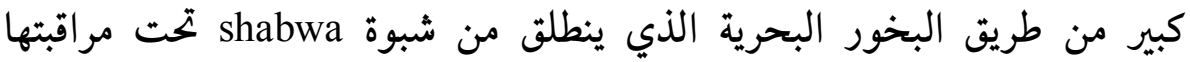

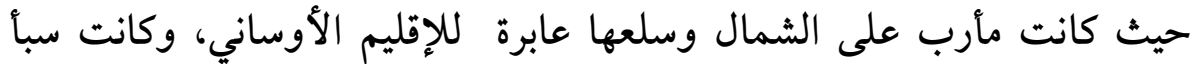

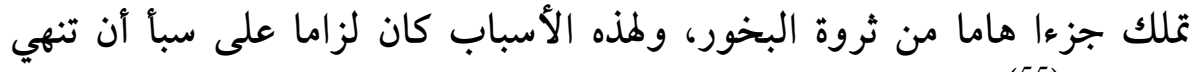
وجودهـ(55).

ي) : tubani العلاقات مع إمارات دهس وتبنو *) الحملة ضد إمارة دهس Dahas: حاربتهم سبأ في عهد المكرب كرب إيل وتر لما

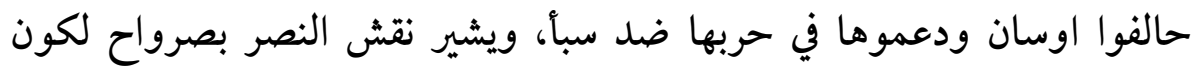
الملك السبئي قد قتل منهم 1000، وأسر

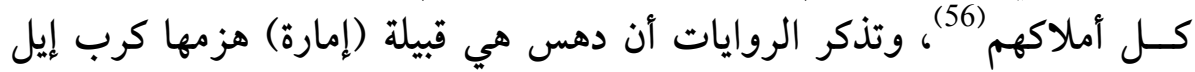

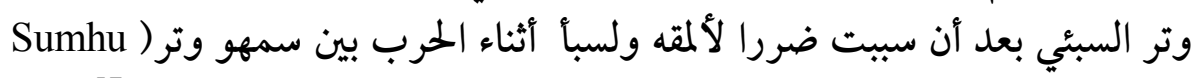

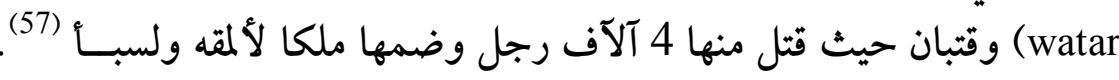
وهكذا وقعت إمارة دهسم ضمن مملات هذا المكرب وكانت مع مع تبني

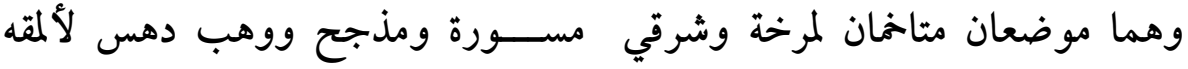

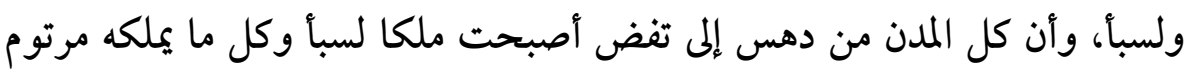

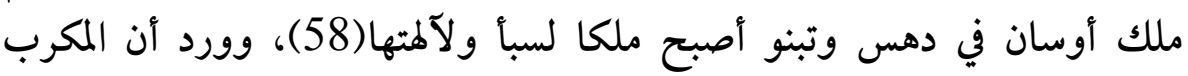

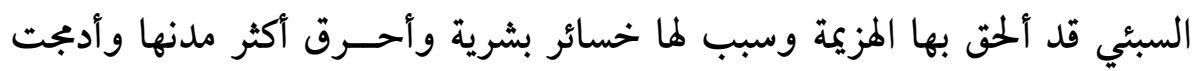

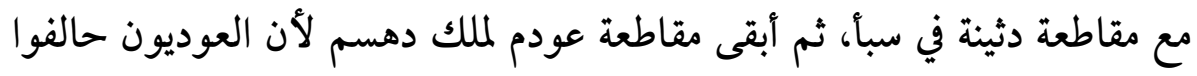
سبـأ . ماطعة

ن) العلاقة مع نجران وتوابعها من المدن والقبائل: 
تخلد النقوش انتصارات ومآثر ملك سبأ الشخصية حيث نجد حملات

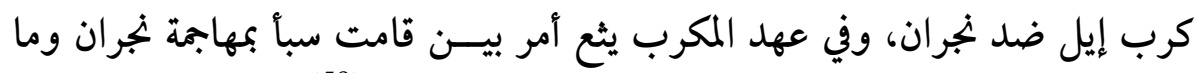

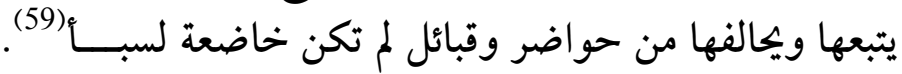
ف) العلاقة مع يلاد الجوف وما يتبعها من الإمارات: : مهأمرم وعوهبم وعمير amir وحرام haram

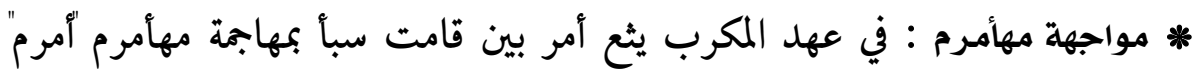

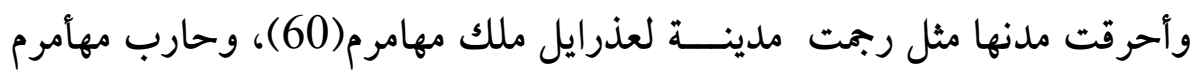

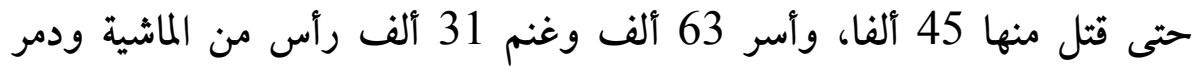

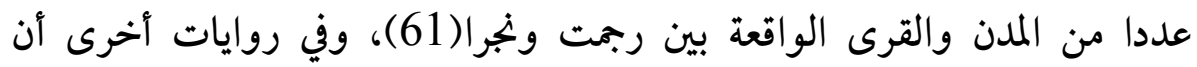

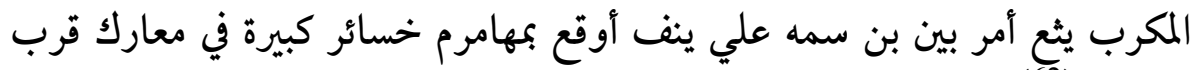
نجــــان المران

لقد حاربت سباً مدينة مهأمرم المملكة حيث شن المكرب كرب إيل وتر

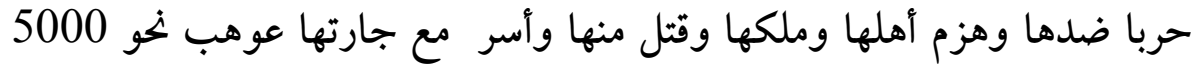

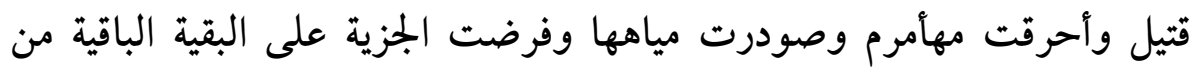

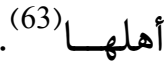

* فإمارة مهامر Muha'mir وجهت لما الحملة السبئية 8 ومععها كانت قبيلة عمير

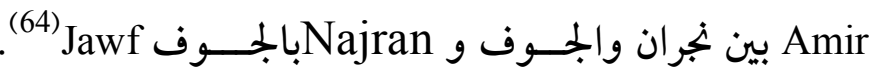
* وكانت إمارة حرام Haram ضمن حملات المكرب السبئي 5 و6 وهي إمارة تمتد

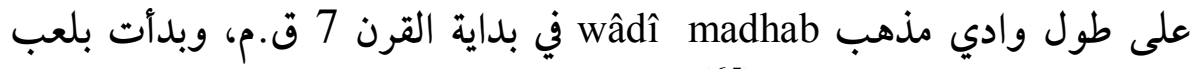

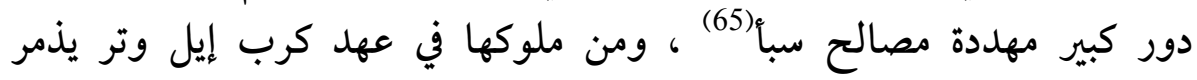

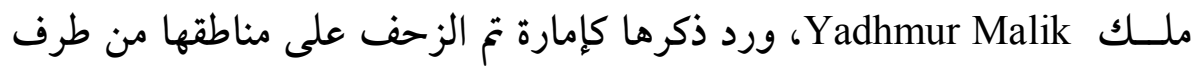
(66) المكرب السبئي الفاتـــح ماتح ز العلاقة مع إمارة نششان nashshân "نشن (الخربة السوداء أو السويداء) : 
*) علاقات الود والتعـاون:

قام الملك السبئي ياسر يهنعم وشريكه ولده ذرأ أمر أيمن في عهد المملكة السبئية 2

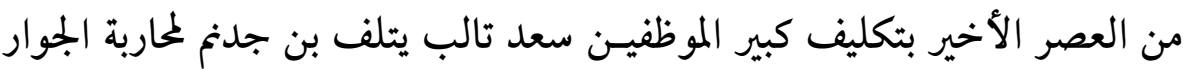

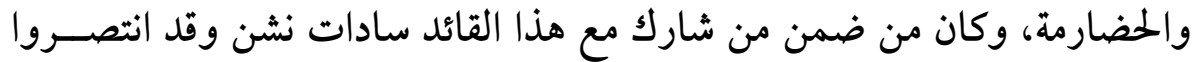

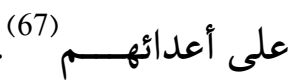

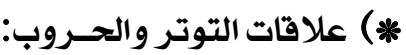

لقد شملتها حرب كرب إيل وتر السادسة حيث بدأت تهدد مصالح سباً كاوسان وباقي يختلف الإمارات وقد افتكت سبأ من ملك نشان(sumhû yafa)

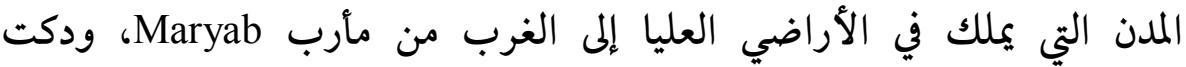
جدرانها وتهدم القصــر الملكي وأحرق، ومع ذلك حافظت المدينة على وضعها

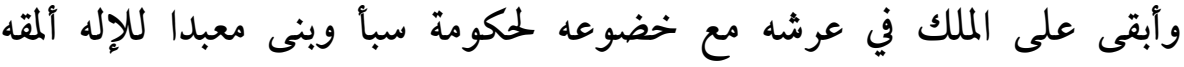

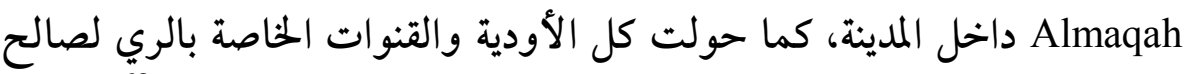
حلفاء سبا، وسورت مدينة نشـــق واحتلت نهائيا من طرف السبئيــن (68). ت) العلاقة مع مختلف الإمارات الأخرى : * العلاقة مع إمارة مفعلم: وهي إمارة ورد ذكرها في ملات المكرب السبئي الفاتح، حيث ذكر انه غلب حضرهمو ملـك مفعلم وانتزع منه منطقة شعبهم

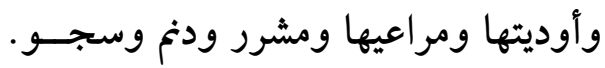

* إمارة وقيه: وورد ذكرها كإحدى الإمارات التي تعرضت لغزو كرب إيل وتر،

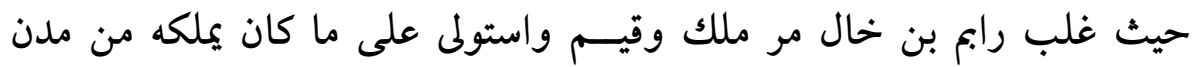
وأراضي زراعية ومناطق مرويـــة (69). * إمارة غرب: وتعرضت لحملات كرب إيل وتر الجوارية حيث غلب خال كرب

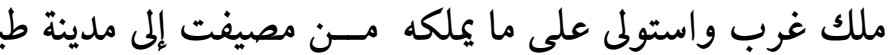


* إمارة سين: فقد ذكر نقش صرواح أن سما ورشاي والأراضي الممتدة من

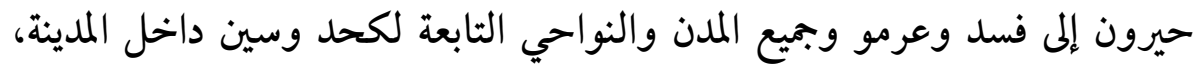

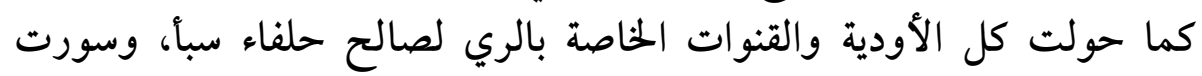

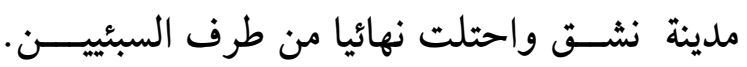
* إمارة المعافر:Ma'âfrân: وهي منطقة يمنية واسعة حيث قام المكرب الفاتح

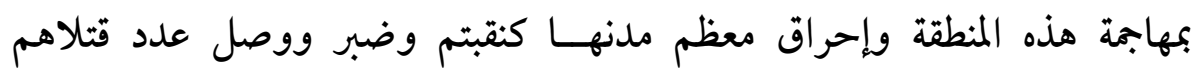

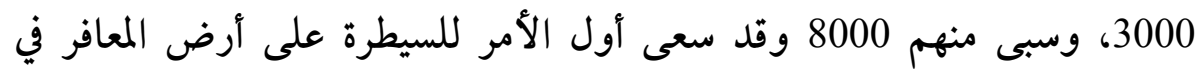

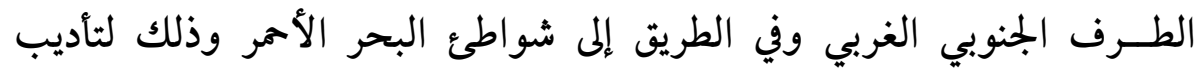

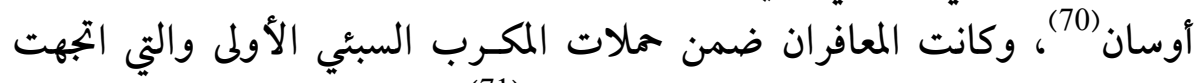
نحو الجنوب الغربي وشملت معافران وذبهــان (71). * إمارة ذبحن: وهي إحدى قبائل الإمارات التي هاجمها كرب إيل الفاتح خلال

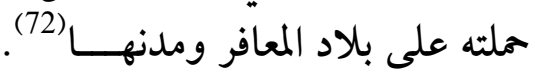
إمارة حمدان : وورد ذكرها في نقش المكرب كرب إيل وتر بصرواح ككيان، وقد

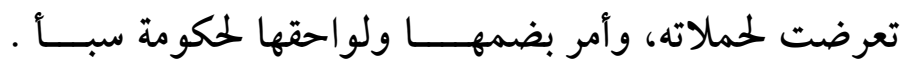
* إمارة أنفم: وهي من بين الإمارات التي تعرضت للحرق من طرف المكرب

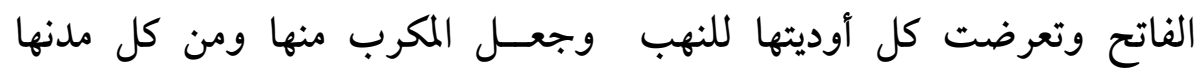
وأراضيها وأوديتها ومراعيها ملكا للمملكة السبئيـــــة (73). * إمارة يفعت: وهي من المناطق والمدن التي ذكرها نقش النصر بصرواح في

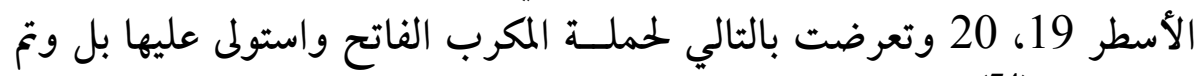

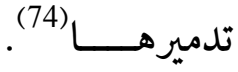

* العلاقة مع نشق(nesca) ومحيطها: لقد حاربت مملكة سبأ مدينة إمارة نشق وضرب عليها الملك السبئي حصــارا دام 3 سنوات ثم ضمها وسقط فيها 1000 قتيل واستولى على أراضيها الزراعية وسدودها وأسكن فيها السبئيين وبنى بها

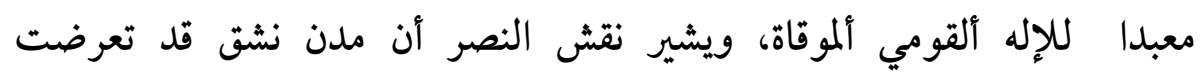




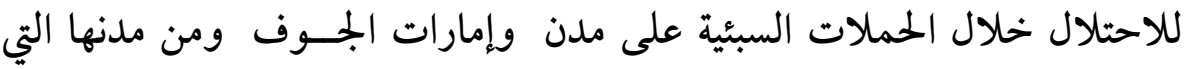

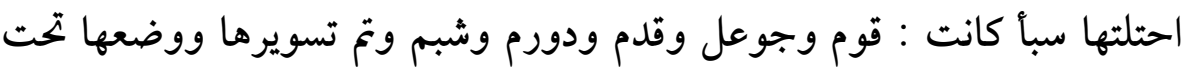

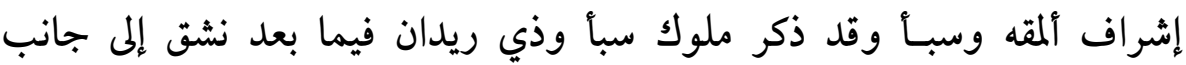
مدنهم المفضلة كمأرب وصنعاء مثل الملك الشرح يحضب وذي وشئ وشمر يهرعش (75). ) علاقاتها الجوارية مع مختلف القبائل والعشائـر: | I العلاقة مع فيشن: يذكر المكرب كرب إيل وتر أنه أضاف لها أثناء فتوحاته

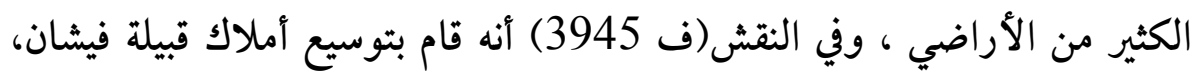

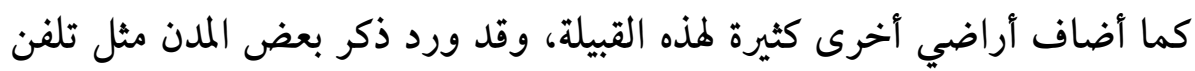

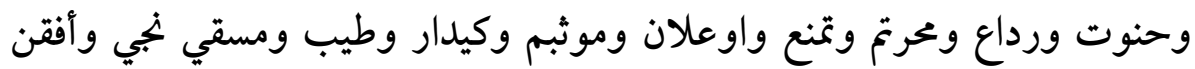

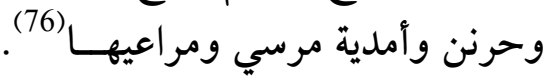

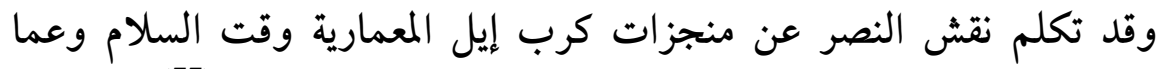

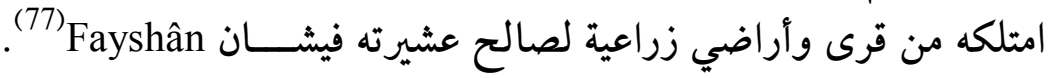
ب) العلاقات مع كحد ذي طوسم (kahd ' dhû - sawt): قام المكرب كرب إيل

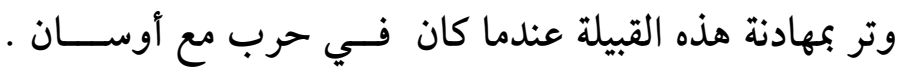
ج) الحروب مع حيان وذيب وجردان بنواحي عرمة : كما قام المكرب كرب إيل إليل وتر في أثناء حروبه التوسعية الجوارية بغزو وديب وجردان بنواحي القبائسـلـ (78).

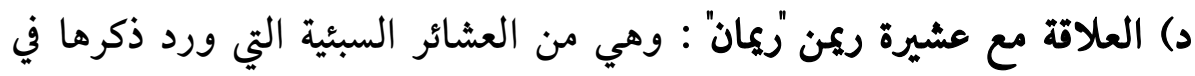

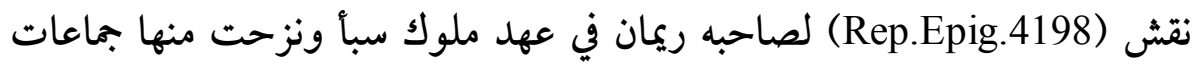

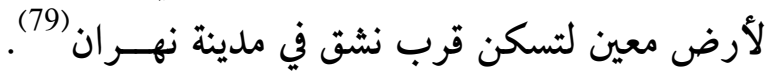

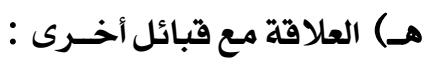
ومنها قبائل بكيل وقبائل شبام وقبيلة أريم أريام" وعشيرة ذمري هوتن (من قبيلة سمهرم) (80) 
وقبيلة ميدعم "ميدع" وقبائــل سمعي ومع قبائل همدان التي كان مركزهم ناعـــ (81)

) علاقاتها مـع مختلف المدن والمناطق والأقاليهم المجاورة:

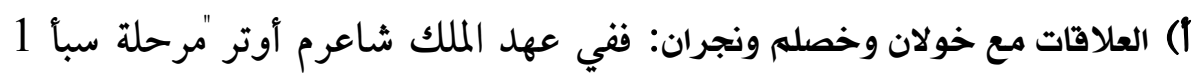

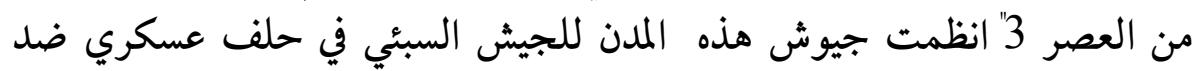

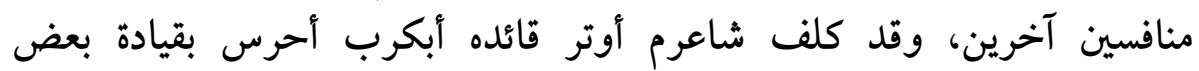

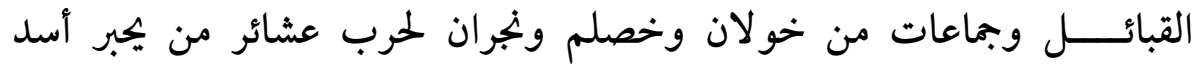

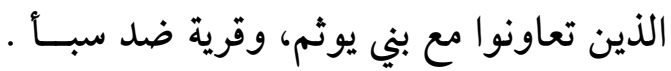
ب) العلاقات مع بلاد الجوف ومدنها :

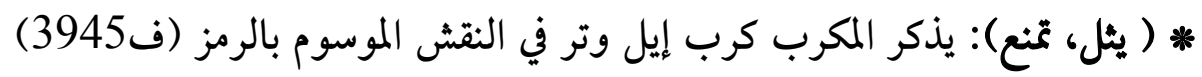

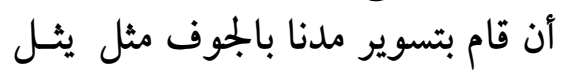

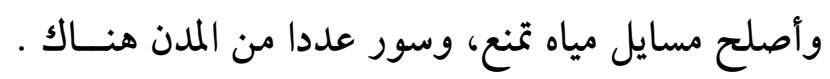

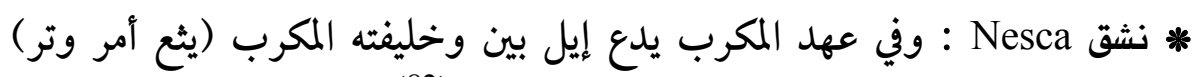

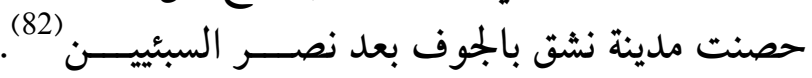
* مدن سبل وهرم وفنن: ورد ذكرها كمناطق زحف عليها المكرب السبئي كرب المبر إيل وتر بعد حربه ضد أوسان (83)

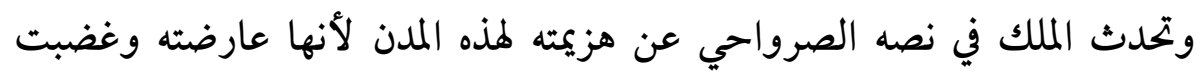

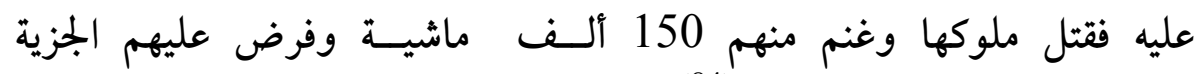

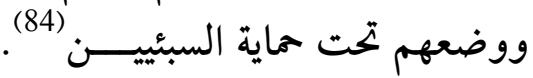


ثانيا/ سياستها وعلاقتها الإقليمية والدولية :

1 ) علاقاتها مع شعوب وممالك وسط وشمالي الجزيرة العربية :

أ) العلاقات مع الشمال عموما: لقد ظلت الكثير من قبائل السبئيين والمنتسبين إليهم

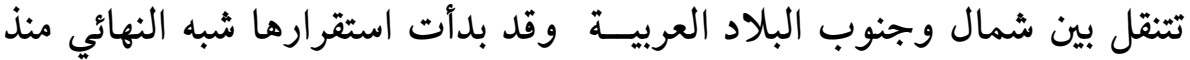

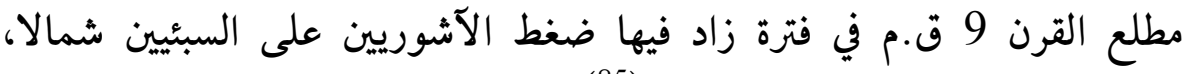

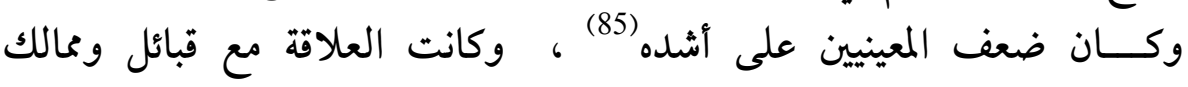

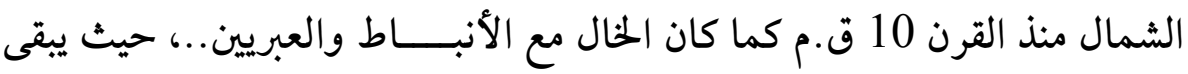

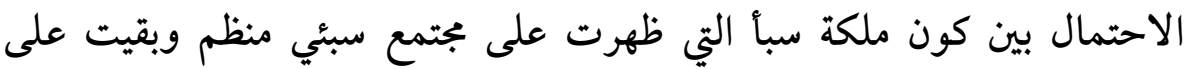

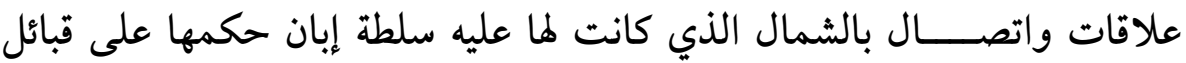

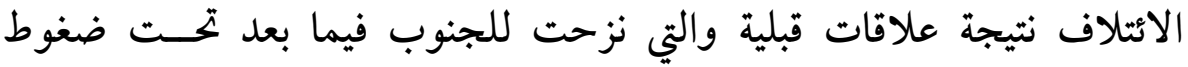

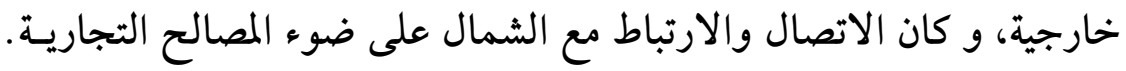
فرغم أن التوسع السبئي وتواجده خارج اليمن لم يكن على غرار تواجد الفرس أو الأحباش فقد كان تواجدا على شكل ان بنـاء الحاميات والممثليات في فئي

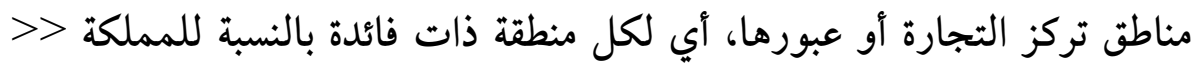

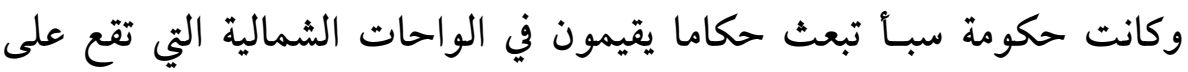

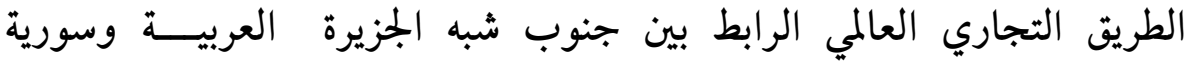

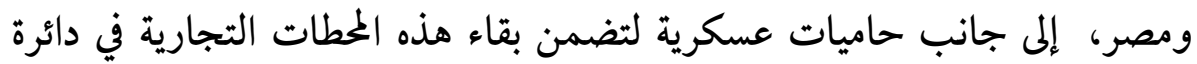
النفوذ السبئي، ومنها واحات ديدن والعلاء كمراكز رئيسية تمارس فيها سبأ نفوذها على شمال بلاد العـرب' (86).

ب) العلاقات مع مملكة الأنبـاط:

كانت مملكة الأنباط تقع شمال غربي الجزيرة العربية بمنطقة سلع

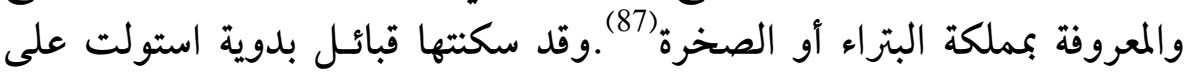
المنطقة منذ القرن 6 ق.م ، وظلت هذه المنطقة بحكم موقعها في ملتقى خط التجارة المجرة 
الرابط بين جنوبي شبه الجزيرة العربية وموانئ سوريا في وضع استراتيجي وحضاري مهم حتى ألحقها الإمبراطور الروماني ترايانــوس (88).

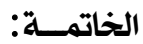

توصلنا لمعرفة قوة وازدهار الحضارة السبئية من خلال تلك العلاقات

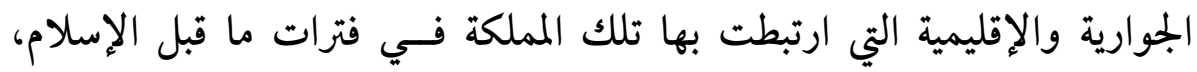
وكانت عاملا قويا في توسع نفوذها التجاري والمالي والسياسـي.

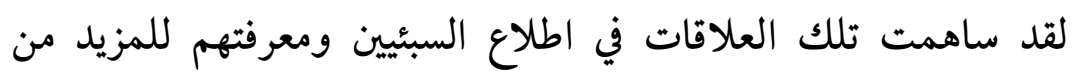

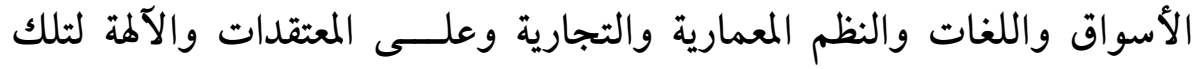

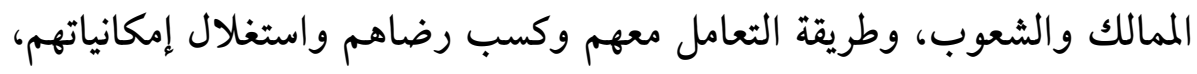

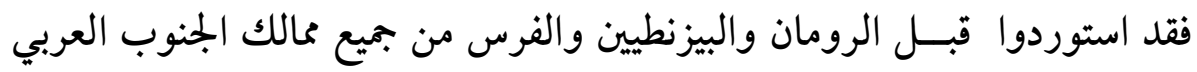

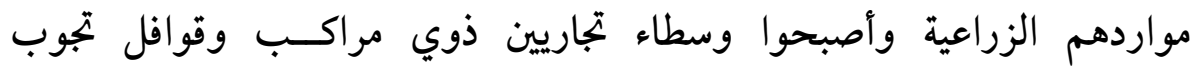

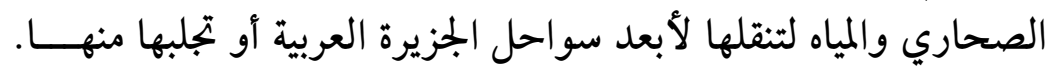
كما استفادت المملكة السبئية من علاقاتها الجوارية بالتحالف والتعاون

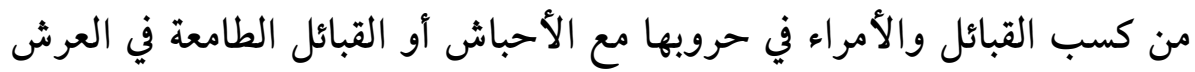

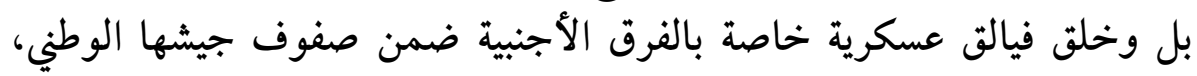

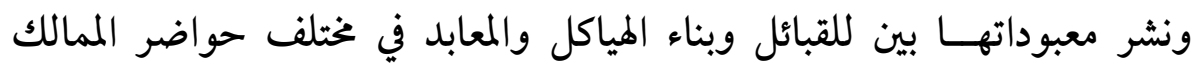

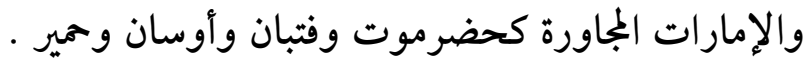

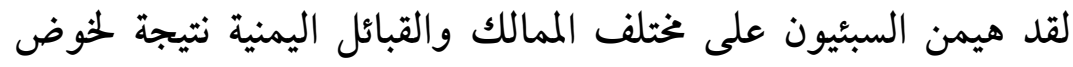

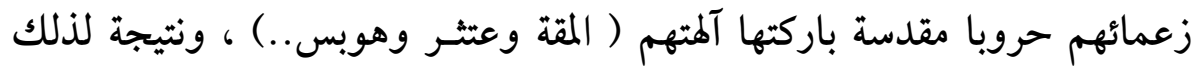

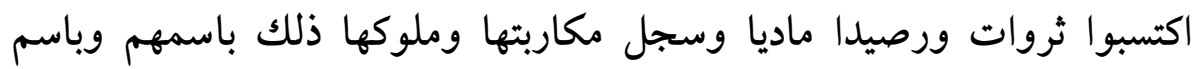

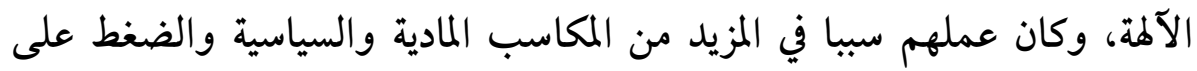

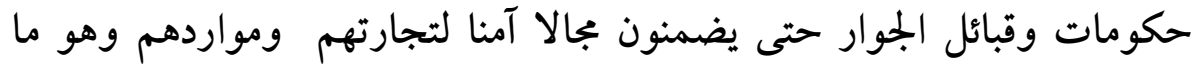

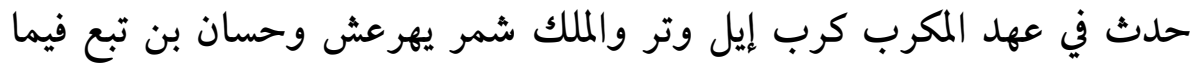


بعد حتى غدت المملكة السبئية أكبر كتلة سياسية في الجنوب العربي قبل

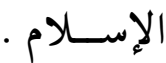

هوامش البحث

(1) Christian julien robin, Fondation d'un Empire, la Domination Sabeenne sur les Premiers Royaumes , 8 -6 eme siécles .av .j . ch, Yémen Au Pays De La Reine De Saba , Flammarion _. Institut Du Monde Arabe, Paris , 1997 ; PP . $89-90$.

محمد عبد القادر بافقيه: تاريخ اليمن القديم، المؤسسة العربية للدراسات والنشر، طبعـة

$$
\text { بيــــــروت ، 1958، ص ص . } 65 .
$$

جواد علي: المفصل في تاريخ العرب قبل الإسلام، ج . 2، دار العلم للملايين، بيروت ،

$$
\text { 1976، ص ص . } 289 \text { - } 290
$$

السيد عبد العزيز سالم: دراسات في تاريخ العرب "تاريخ العرب قبل الإسلام" منشورات شباب الجامعة للطباعة والنشر الإسكندرية، 1974، ص ـ ـ 107.

$$
\text { جواد علي: مرجع سبق ذكره، ص ـ } 288 .
$$

محمد عبد القادر بافقيه: مرجع سبق ذكره، ص . 113.

سباتينو موسكاتي: الحضارات السامية القدية، ترجمة السيد يعقوب بكر ، دار الرقي،

$$
\text { بيـروت ، 1986، ص ص ـ } 192 \text { - } 193 .
$$

Christian Julien $\quad \leq$

$$
\begin{array}{r}
\text { محمد عبد القادر بافقيه: مرجع سبق ذكره، ص . } 114 \text { Robin, Op, Cit , P . } 94
\end{array}
$$


(10) Christian Julien Robin , Op . Cit , P. 96.

(11) Bayoumi . Med . Mahran, Studies In Ancient History Of The Arabs, National Offest Printing Press, Riyadh, 1977, P. 281.

$$
\begin{aligned}
& \text { (12) السيد عبد العزيز سالم : مرجع سبق ذكره، ص . } 110 . \\
& \text { جواد علي: مرجع سبق ذكره، ص . } 321 . \\
& \text { (14) المرجع السابق ، ج2 ، ص . } 418 \text {. }
\end{aligned}
$$

(15) Bayoumi . med . mahram, Op . Cit, P . 319 .

$$
\begin{aligned}
& \text { (16) السيد عبد العزيز سالم : مرجع سبق ذكره، ص . } 113 \text {. } \\
& \text { (17) جواد علي: مرجع سبق ذكره، ص . } 99 \text {. }
\end{aligned}
$$

(18) مهران.م •بيومي: دراسات في تاريخ العرب القديم " تاريخ العرب قبل الإسلام" ، ج .2، ط 10 المطبعة الأهليـــة للأوفست، الرياض، 1977 ، ص .291 .

$$
\begin{aligned}
& \text { (19) جواد علي: مرجع سبق ذكره، ص ص . } 536 \text { - } 540 . \\
& \text { مهران · م · بيومي: مرجع سبق ذكره، ص . } 283 \text {. } \\
& \text { (21) محمد عبد القادر بافقيه: مرجع سبق ذكره، ص . } 65 . \\
& \text { (22) المرجع السابق ، ص . } 111 . \\
& \text { محمد عبد القادر بافقيه: مرجع سبق ذكره ، ص . } 113 . \\
& \text { جواد علي: مرجع سبق ذكره، ص . } 549 \text {. }
\end{aligned}
$$




$$
\begin{aligned}
& \text { (25) المرجع السابق، ص ص .557 ـ } 563 \text {. } \\
& \text { (26) محمد عبد القادر بافقيه: مرجع سبق ذكره ، ص ص . } 105 \text { ـ } 109 . \\
& \text { (27) جواد علي: مرجع سبق ذكره ، ج · } 2 \text { ، ص . } 424 . \\
& \text { (28) (المرجع السابق ، ص } 226 .
\end{aligned}
$$

${ }^{(29)}$ Christian julien robin, Op . Cit , P . 94 .

$$
\begin{aligned}
& \text { (30) مهران. م. بيومي : مرجع سبق ذكره، ص . } 283 . \\
& \text { (31) السيد عبد العزيز سالم : مرجع سبق ذكره، ص . } 112 . \\
& \text { سبتينو موسكاتي: مرجع سبق ذكره، ص . } 49 . \\
& \text { جواد علي: مرجع سبق ذكره، ص . } 54 . \\
& \text { السيد عبد العزيز سالم : مرجع سبق ذكره، ص ـ } 110 . \\
& \text { جواد علي: مرجع سبق ذكره، ص . } 321 .
\end{aligned}
$$

ذو ك.

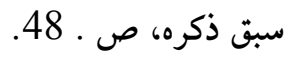

${ }^{(37)}$ Christian Julien Robin, Op . Cit, P . 94.

$$
\text { جو سباتينو موسكاتي: مرجع سبق ذكره، ص . } 54 .
$$


(40) (المرجع السابق ، ص . 54 .

(41) Bayoumi, med . mahram, op, cit, P . 291.

(42) IBID, P . 37

$$
\text { السيد عبد العزيز سالم : مرجع سبق ذكره، ص . } 100 \text {. }
$$

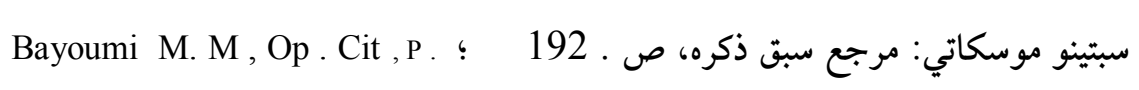

(45) IBID, P 294.

(46) IBID , P . 37

${ }^{(47)}$ IBID , PP . $83-96$.

${ }^{(48)}$ IBID , PP. 317 - 318 .

(49) السيد عبد العزيز سالم : مرجع سبق ذكره، ص . 108.

(50) السيد عبد العزيز سالم: مرجع سبق ذكره، ص . 112 ؛ جواد علي: مرجع سبق ذكره ، ص . 287

$$
\text { (51) السيد عبد العزيز سالم: مرجع سبق ذكره ، ص . } 107 \text {. }
$$

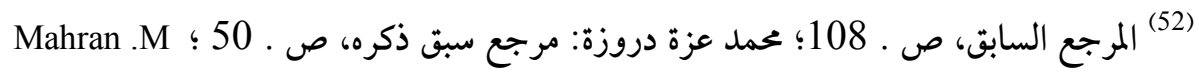
. B, Op . Cit , P. 276

(53) مهران · م · بيومي : مرجع سبق ذكره، ص . 28.

(54) جواد علي: مرجع سبق ذكره، ص ص . 289 - 290 ؛ محمد عبد القادر بافقيه: مرجع

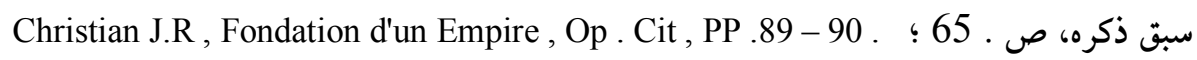


(55) Nober Nebes, karib 'il Watar Premier Unificateur du Yemen, Yémen Au Pays De La Reine De Saba , Flammarion Institut Du Monde Arabe , Paris , 1997 ; P. 95 .

$$
\text { (56) مهران م. بيومي: مرجع سبق ذكره، ص. } 283 \text {. }
$$

(57) Christian Julien Robin, Op, Cit , P. 94.

$$
\begin{aligned}
& \text { (58) سباتينو موسكاتي: مرجع سبق ذكره، ص . 48. } \\
& \text { (59) جواد علي: مرجع سبق ذكره، ص ص . } 287 \text { - } 290 \text {. } \\
& \text { (60) المرجع السابق، ص . } 287 .
\end{aligned}
$$

${ }^{(61)}$ Bayoumi . Med. Mahram, Op, Cit , P. 281.

${ }^{(62)}$ PHilby, Le Muséon, Lx2 , 3,4, 1949 , P. 249.

$$
\text { سباتينو موسكاتي : مرجع سبق ذكره، ص . } 48 \text {. }
$$

(64) Christian Julien Robin, Op . Cit, PP . 89-91 .

${ }^{(65)}$ Nober Nebes, karib'il Watar premier unificateur, Op . Cit , P .95 .

$$
\begin{aligned}
& \text { (66) سباتينو موسكاتي : مرجع سبق ذكره، ص . } 48 . \\
& \text { (67) جواد علي: مرجع سبق ذكره، ص . } 557 \text {. }
\end{aligned}
$$

${ }^{(68)}$ Christian Julien Robin, Op . Cit , P . 96.

; N Nober Nebes , Karib'î 1Watar , Op . Cit , P.95 . (69) ذكره، ص .

${ }^{(70)}$ Christian Julien Robin, Op . Cit, P 90. 
${ }^{(71)}$ Norber Nebes, Karib'îl Watar, Premier Unificateur du Yemen, P . 95.

(72) IBID.

$$
\begin{aligned}
& \text { (73) جواد علي: مرجع سبق ذكره، ص } 290 . \\
& \text { (74) المرجع السابق: ص . } 295 . \\
& \text { (75) المرجع السابق: ص ص . } 557 \text { - } 295 \text {. }
\end{aligned}
$$$$
\text { (76) سباتينو موسكاتي : مرجع سبق ذكره ، ص . } 48 .
$$

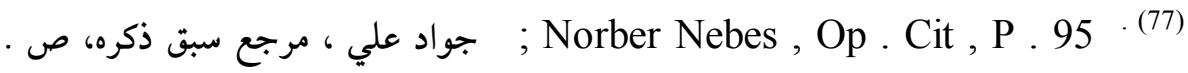

$$
\text { (78) جواد علي : مرجع سبق ذكره ، ص ص . } 290 \text { - } 298 \text {. }
$$

${ }^{(79)}$ Philby, Le Musion ,1964, P . 436.

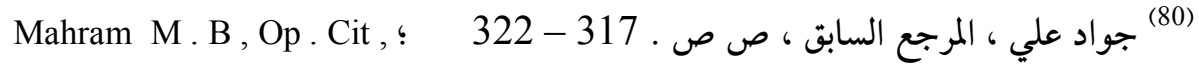
PP .24- 28 .

(81) جواد علي: مرجع سبق ذكره ، ص ص • 99 - 290 ؛ السيد عبد العزيز سالم ، مرجع سبق ذكره ، ص ص 113.

(82) السيد عبد العزيز سالم: مرجع سبق ذكره، ص • 112.

سباتينو موسكاتي : مرجع سبق ذكره، ص . 48.

جواد علي: مرجع سبق ذكره، ص . 294 .

السيد عبد العزيز سالم: مرجع سبق ذكره، ص . 108 . 


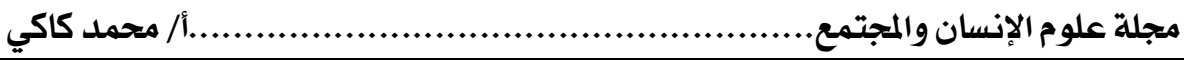

(86) ابن خلدون عبد الرحمان: كتاب العبر، دار الكتاب اللبناني، المجلد 2، 1981، ص. 109 . (87) لويس معلوف: البتراء "الثغرة"، منجد الأعلام، الطبعة ـ21، المطبعة الكاثوليكية، دار المشرق ، بيروت ، 1973 ص . 117 . 117 . (88) 